\title{
Entre-modos. Um jogo de re-perguntas à volta do Modo Operativo AND
}

\section{In-between modes. A game of re-questioning with Modus Operandi AND}

Milene Lopes Duenha

Fernanda Eugénio ${ }^{2}$ Ana Dinger ${ }^{3}$ 


\section{Resumo}

Um conjunto de inquietações acerca das relações entre corpo, linguagem, modos de fazer e modos de vida, emergentes da vivência intensiva de um curso organizado pelo AND_Lab Centro de Investigação em Arte-Pensamento \& Políticas de Convivência em Lisboa (PT), serviu de disparador para um jogo de re-perguntas à volta das ferramentas ético-estéticas do Modo Operativo AND (MO_AND). Tomando a forma de conversa e de pensamento ao vivo, este jogo foi traçando um território de problemas na medida em que o percorria, desdobrando questões de duração, etnografia e escala na prática do MO_AND, e as relações-tensão sobre vs com, atenção vs disponibilidade, ética vs estética e arte engajada vs engajamento.

Palavras-chave: Modo Operativo AND; Práticas Ético-Estéticas; Com-Posição; Corpo; Linguagem.

\section{Abstract}

A set of concerns regarding the relationship between body, language, ways of doing and ways of life, emerging from the intensive experience of a course organized by AND_Lab Research Centre in Art Thinking \& Politics of Togetherness held in Lisbon (PT), served as the trigger for a game of re-questioning around the ethical and aesthetic tools of the Modus Operandi AND (MO_AND). Taking the form of a conversation and thinking live, this game drew a territory of problems as it was unfolded, addressing questions such as duration, ethnography and scale in the practice of MO_AND, and the tension-relation of about vs. with, attention vs. awareness, ethical vs. aesthetics and engaged art vs. engagement.

Keywords: Modus Operandi AND; Ethical-Aesthetics practices; $\mathrm{Co}(\mathrm{m})$ position; Body; Language.

ISSN: 1414.5731

E-ISSN: 2358.6958
1 Doutoranda no Programa de Pós-Graduação em teatro (UDESC). Atriz, bailarina e performer. miduenha@yahoo.com.br

2 Antropóloga, multiartista, investigadora e docente. Professora convidada em diversos programas de formação em ciências sociais, artes e performance (inter)nacionais. fe.eugenio@gmail.com 
Uma proposta intensiva que reunia vários profissionais das áreas da dança, antropologia, teatro e performance para co-experimentar e encontrar ENTRE-MODOS de fazer. Esse era o convite da Escola de Verão AND 2016 | \#1 Entre-modos de fazer, realizada pelo AND_Lab Centro de Investigação em Arte-Pensamento \& Políticas de Convivência, entre 1 e 16 de Julho no Pólo Cultural Gaivotas Boavista, em Lisboa. O programa colocaria em relação a pesquisa desenvolvida atualmente por Fernanda Eugénio no Modo Operativo AND, e as pesquisas dos artistas, professores e investigadores convidados Ana Dinger, Ana Mira, Francisco Gaspar Neto, Gustavo Ciríaco, Mariana Ferreira, Sílvia Pinto Coelho e Soraya Jorge, em oficinas como Metálogo \& Co-operação, Corpo-Gesto \& Construção de Documentos Sensíveis, Deriva \& Arrumação, Etnografia Circunscriptiva \& Performance Situada, Práticas de Atenção, Corpo-Presente \& Escutação.

O encontro aconteceria do outro lado do Atlântico. Perdi o vôo. Comprei outro bilhete. Dois dias em trânsito. Primeira vez na Europa. Foi intensivo em vários aspectos. A Escola de Verão AND 2016 | \#1 Entre-modos de fazer propiciou muitos entres por meio de um descobrir/fazendo que convidava, durante todo tempo, a novos modos de olhar, de conviver. A propósito, esse já é um relevo que caracteriza o Modo Operativo AND, um modo de fazer etnográfico que emerge e re-existe na intersecção entre ética e estética, inventando mundo no ato de com-por, pôr-se com o outro usando aqui algumas das expressões e ferramentas-conceito do vocabulário AND. A comunidade momentânea que se forma é responsável pela gestão de um plano comum de atuação que se estabelece no encontro entre corpos (pessoas e objetos), cujas posições e consequências fazem e refazem corpo, pensamento e modos de vida.

O Modo Operativo AND surge de uma pesquisa na área da antropologia, ganhando contornos específicos na relação com o campo da Performance. Abordando a etnografia enquanto "performance situada do encontro", abre caminho para o seu uso transversal (da criação artística à mediação de relações no quotidiano), permitindo que esta se revele na sua perspectiva de tomada de posição, por meio de uma atenção às matérias que se colocam em jogo. Tal abordagem põe em questão noções de significado, autoria, protagonismo do sujeito e hierarquia ao investir em práticas de convívio colaborativo, experimentando, a cada novo momento, a pergunta: Como viver juntos?

Nesse encontro, entre as ferramentas do Modo Operativo AND e as das outras práticas voltadas a um refinamento da atenção, ao experimentarmos escalas micro e macro - que vão de corpo à cidade, à vida - muitos mundos surgiram. Questões ebuliam em mim, e a vontade de dividir com o mundo aqueles mundos possíveis, que insurgiam em ato, impulsionou-me ao convite à Ana Dinger e à Fernanda Eugénio a realizarem o que se verá desenhado aqui nestas páginas. Trata-se de uma conversa entre as duas, que se inicia por uma primeira posição/provocação, tomada por mim, como efeito dos questionamentos emergentes nessa experiência intensiva.

Tal posição carrega uma tentativa de problematizar escrita acadêmica e fazer artístico por meio desse modo de fazer que não se ocupa em definir o que as coisas são, em uma lógica afirmativa do é, substituindo-o pelo e, convidando a se perceber o que tem, a cada nova situação. Essa substituição de palavras do Modo Operativo 
AND aparece na prática como um desafio a noções de criatividade e de sujeito identitário, uma vez que o corpo é também percebido como coisa, o que exige uma atenção a si e ao entorno, e uma constante gestão do ego. Algumas das questões que me ocorreram nas experimentações e descobertas de entre-modos de fazer são, então, expostas à Ana Dinger e Fernanda Eugénio como um desdobramento desse encontro entre vários, e que pode provocar outros entres. São elas:

Como a invenção de outros modos de operar que implicam uma estreita relação entre ética e estética, a exemplo do AND, pode se presentificar no uso das palavras, mais especificamente no espaço destinado a uma escrita acadêmica sobre a arte? Seria possível uma configuração que explicite uma indissolubilidade entre conteúdo e forma, arte e mundo, mundo e arte? O que tem no AND que pode vir a calhar como ferramenta no encontro entre corpos e palavras? Como as palavras, usualmente identificadas no campo do significado e da representação podem ser deslocadas para outro campo? Seria possível um uso das palavras (conceitos articulados) sem percebê-las somente como ferramentas de interpretação do mundo? Uma espécie de oráculo da vida?

A questão da centralidade do corpo, e de um sujeito identitário como foco na produção em arte é alvo de inquietações, e a discussão do lugar do sujeito nos modos de convívio que aparecem no AND emerge como possibilidade de problematizá-lo em relação a outros corpos. Que elementos interrogariam um corpo sujeito ensimesmado (por muitas vezes estimulado em processos de criação artística), convidando-o a um corpo coisa, disponível para tornar-se, a cada novo instante, matéria justa, à altura do acontecimento?

Diante de acontecimentos que implicam diferentes instâncias de relações, de problemas ambientais/sociais que ressoam nas diversas formas de vida, como coexistir? Como re-existir, reparar? Se o AND aparece como modo de criar mundo, comunidades momentâneas nas quais outros modos de existir são experimentados, como encontrar reverberação e certa incidência na vida social, passando de um microcosmo a um macrocosmo e vice-versa. E como esse modo de inventar mundo pode ganhar cada vez mais mundo, sem um olhar de superioridade, de criação? Como olhar esse fazer na arte, por exemplo?

Milene Lopes Duenha 


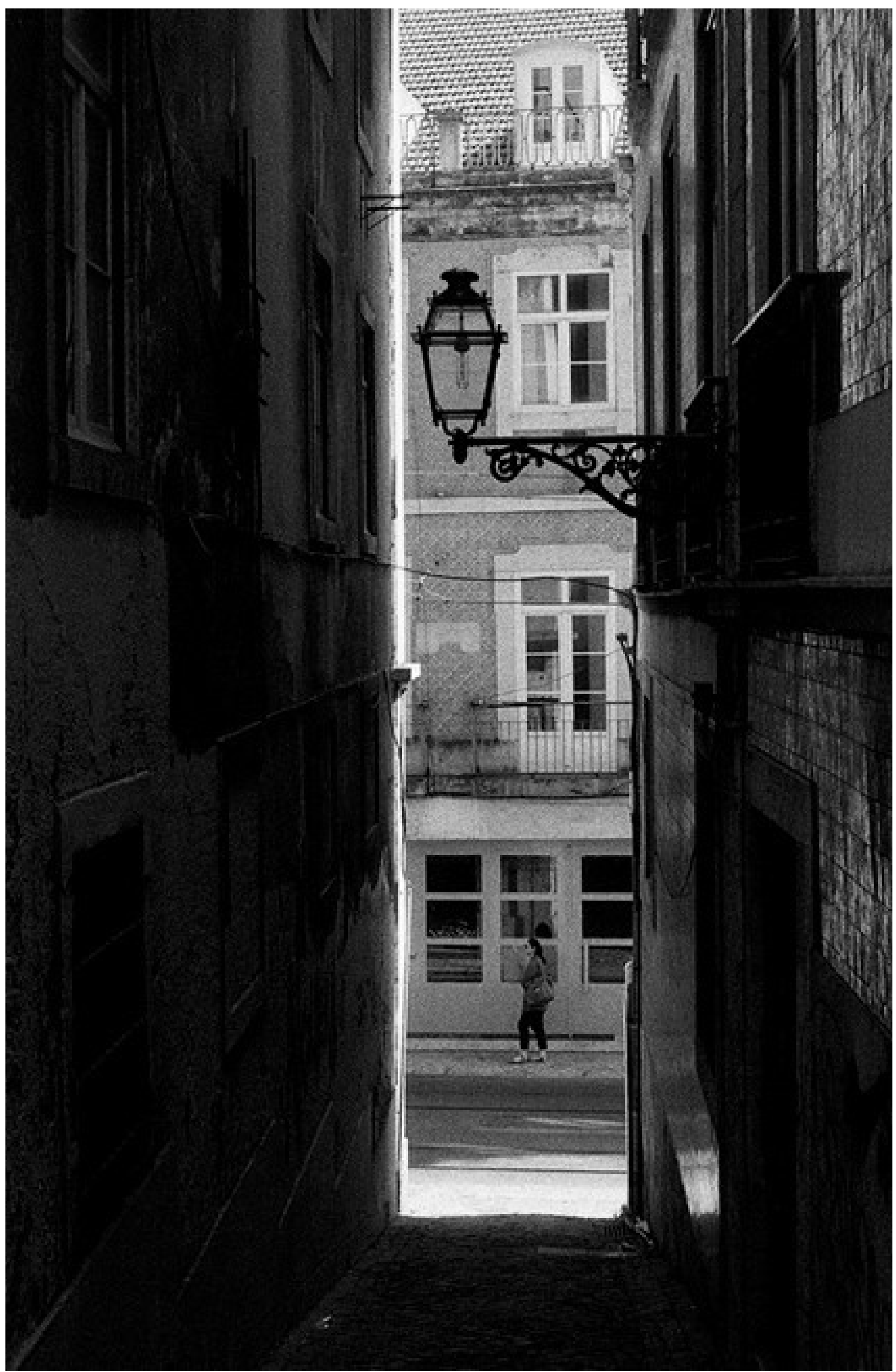

Foto: Filipe dos Santos Barrocas 
A proposta da Milene nos chegou através de um e-mail com sete perguntas -proposições curtas que, agora nos damos conta, correspondem às indagações por ela expostas, de modo mais detalhado, acima. O convite que nos dirigiu incluía ainda indicações de como usar essas proposições, abrindo a possibilidade de variar a ordem ou mesmo descartar uma ou mais questões. Optamos por mapear cada pergunta, utilizando já as ferramentas de circunscrição e enunciação do AND, chegando a um conjunto de problemas-síntese, que nos permitiram entrar numa conversa orientada pelo funcionamento do re-perguntar. Através desta operação, acabamos por percorrer o seguinte território de problemas, alguns deles organizados numa lógica de relação-tensão - sobre vs com, atenção vs disponibilidade, ética vs estética, arte engajada vs engajamento - e outros mais ligados a aspectos da prática do Modo Operativo AND - a duração, a etnografia, a escala.

As oficinas da Escola de Verão AND 2016 | \#1 Entre-Modos de Fazer, realizadas no Pólo Cultural das Gaivotas entre 1 e 16 de julho de 2016, bem como as atividades dos participantes pelas ruas e entorno de Lisboa durante o curso, foram documentadas pelo fotógrafo Filipe dos Santos Barrocas, dando lugar a um ensaio, cujo nexo se articula por posição-com-posição de imagens, em conversa com o funcionamento do Modo Operativo AND. Para esta publicação, Filipe selecionou doze das imagens desse ensaio e as dispôs numa nova sequência-jogo.

Ana Dinger e Fernanda Eugénio

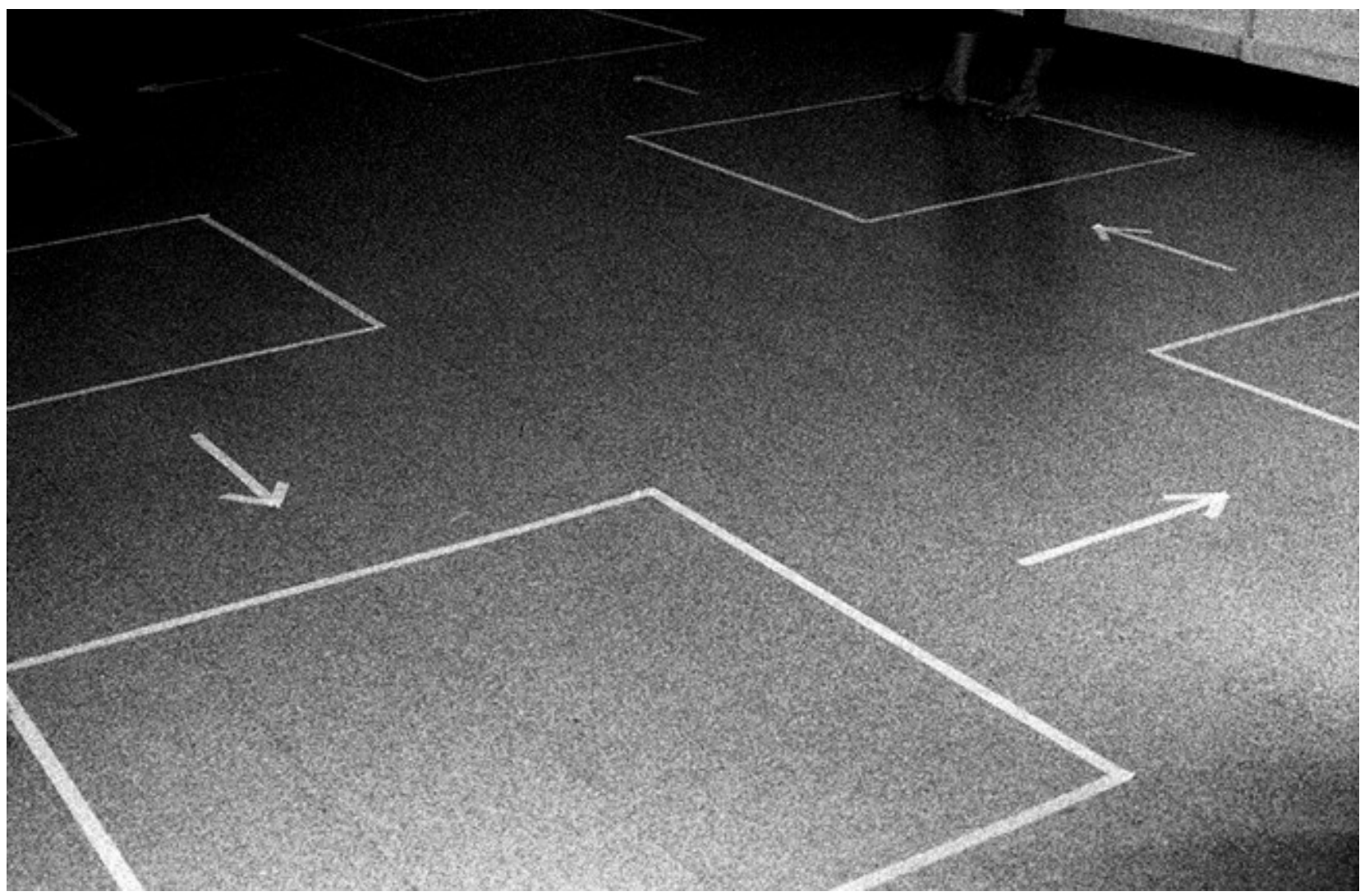

Foto: Filipe dos Santos Barrocas 
A _ O AND trabalha na dobra entre o fazer e o pensar. A fala - considerada eventualmente a materialização desse pensar - pode tornar-se um fazer-com além de sobre. Podíamos começar por nos concentrarmos neste com, eventualmente articulado com a questão da reciprocidade; esse com não ser só um fazer com a matéria mas o fazer (d)a matéria com o outro.

F _ Um dos jeitos de falar do fazer-com tem a ver com o recurso laboratorial de fazer com materiais, como uma maneira de exercitar a dobra, essa relação recursiva entre fazer, pensar sobre o que estou fazendo, conseguir executar o que estou pensando... E essas coisas irem ganhando um ritmo de retroalimentação a ponto de acontecerem mais ou menos ao mesmo tempo. A outra zona do fazer-com é essa do fazer com os outros, usando ou não materiais. Vão estar lá sempre matérias mas essas matérias podem não ser as do laboratório, podem ser as matérias do quotidiano também. Em ambos os casos, as matérias são aquilo que está entre aqueles que estão fazendo - sem contar que aqueles que estão fazendo são, também eles, matéria.

A _ Eu tenho pensado se o uso laboratorial evidencia esse com e se no uso quotidiano não será mais difícil destrinçar o com do sobre. Se calhar, mais uma vez, dependerá da situação de que estivermos a falar porque o quotidiano abarca muitas situações diferentes. Mas lido com a dúvida, às vezes, de onde acaba este com e o sobre começa. Ou se haverá entre eles, por vezes, uma separação tão clara que nos permita, num trabalho de auto-observação e auto-regulação, distingui-los.

F _ Quando estamos a discutir isso, por exemplo, no campo da criação artística, a diferença entre fazer-sobre e fazer-com talvez seja mais evidente - ou é mais evidente só porque já exploramos mais essa questão. Há uma tendência a começar por representar ou por executar uma ideia feita, a fazer-sobre ela. Mas há outro funcionamento, mesmo que minoritário em relação a este: o do fazer-com o que se apresenta (situações, coisas, encontros), sem ideia prévia, permitindo que o trabalho vá emergindo como consequência. No quotidiano, essas duas tendências - representar e presentar - também se manifestam. Mas talvez existam nuances no sobre que ficam mais explícitas neste plano. Eu acho que, no quotidiano, podemos distinguir, talvez, dois modos de fazer-sobre algo: um que tem mais a ver com uma 'invenção do assunto' e, a partir de então, o sobre ser qualquer coisa da ordem de uma disputa entre pontos de vista; outro que poderia ter a ver com fazer algo a respeito de. Não é sobre algo, no sentido de transformá-lo numa espécie de assunto ou de tema a ser discutido e escrutinado para que se chegue a uma verdade ou a um diagnóstico ou uma opinião. É, antes, ter em consideração uma questão que surge e em relação à qual é preciso fazer alguma coisa. Ela não pode ser ignorada. Se for nessa voltagem, o sobre e o com começam a ficar parecidos.

A _ Entre esses dois modos do sobre pode, talvez, um estar mais ligado a uma ética de manuseamento e o outro, por oposição, a um uso mais manipulativo ou usurpador. Sendo que a manipulação do assunto pode não ser necessariamente mal intencionada. A manipulação ou usurpação podem nem ser da ordem daquilo que é 
consciente. Remetendo para a própria escrita acadêmica, é muito notória, às vezes, não só essa tendência para inventar o assunto como forçar, ou mesmo forjar, uma série de associações que fazem das coisas analisadas exemplos da ideia prévia que se tem sobre elas. Às vezes até negligenciando outras dimensões ou outros aspectos do que se está a tentar analisar. Parte deles são, de certa forma, obscurecidos, camuflados ou ignorados, em prol da coerência de uma ideia-tese que se quer passar. Então, são os perigos desse sobre, que é mais impositivo, ou até colonizador, que me preocupam. Mas agrada-me essa possibilidade de haver dois modos ou duas modulações ou voltagens do sobre.

F _ Talvez se possa pensar que há uma voltagem do sobre, aquela do a-respeitode, que é um trabalho de cuidado e de manuseamento de um problema que ninguém escolheu mas que se apresenta, de modo que não é possível, eticamente, se abster, sob pena de não-comparecimento. O outro sobre, aquele que envolve a construção da coerência, de fato ativa uma tendência a manipular, como você estava dizendo. Selecionar os exemplos ou imagens que convêm... Neste caso, é um só discurso, que se deseja unívoco, que está sendo alimentado. Por exemplo: na escrita acadêmica, isso pode corresponder à tendência de reter apenas as citações que amparam aquele argumento, ir buscar somente os autores que concordam com aquilo... Se for numa pesquisa mais ligada ao campo, o nativo fala só 'na hora que interessa' e só fala os bocados escolhidos para confirmar a tese que está sendo defendida. Ou, ainda, se for na criação de uma peça, as matérias que entram são só aquelas que contribuem para aquele sobre vingar e ficar fechado numa dramaturgia coerente - todas as outras matérias, ou corpos, ou coisas, ou movimentos, que não reiteram aquela direção, são eliminados. Em inglês, por exemplo, é possível traduzir o sobre como about ou como on. Em português não dá: tem o a-respeito-de, que talvez seja o equivalente ao on, mas não tem um sinônimo para esse sobre mais ligado à coerência, que talvez seja o equivalente ao about.

\section{A _ Mas o on também pode ter uma dimensão de em-cima-de...}

F _ Mas ficar por cima não tem necessariamente esse sentido de se sobrepor ao afeto. Talvez tenha mais um sentido de ligação, de entrar on, de se colocar em sintonia. O about talvez seja mais da ordem da construção de um território com contornos ou fronteiras definidos - esse tema coerente -, não se determinando só o território mas tudo o que o povoa e o que não o pode povoar. $O$ on, se o aproximarmos a um fazer-a-respeito-de ou a uma sintonização com o alheio, envolve a construção de um plano de consistência, ou seja, não fronteiras coerentes mas limites consistentes. Agora, ainda dentro do pensar e do fazer em simultâneo, se o sobre for colocado nessa lógica de a-respeito-de, ele é o lugar em que o pensamento praticado ou investido no problema se materializa, ao mesmo tempo que o fazer acompanhado do pensamento praticado é um fazer-pensado ou um fazer-pensante. É aqui que a operação do sobre se aproxima da operação do com, porque ao se trabalhar a respeito do problema que emerge o que se está a fazer é acolher o acidente: nesta voltagem, não é possível fazer sobre sem fazer com. 


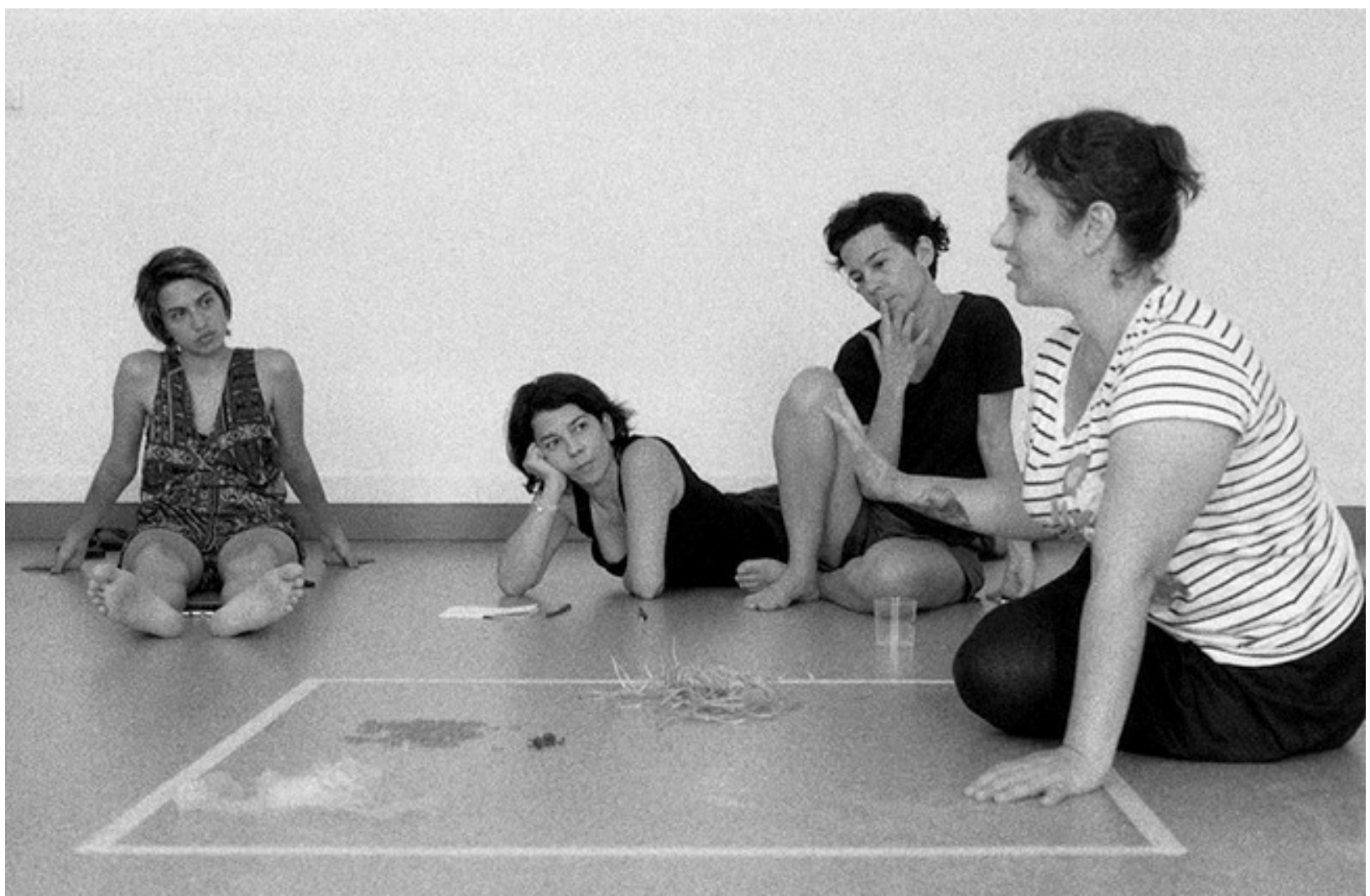

Foto: Filipe dos Santos Barrocas

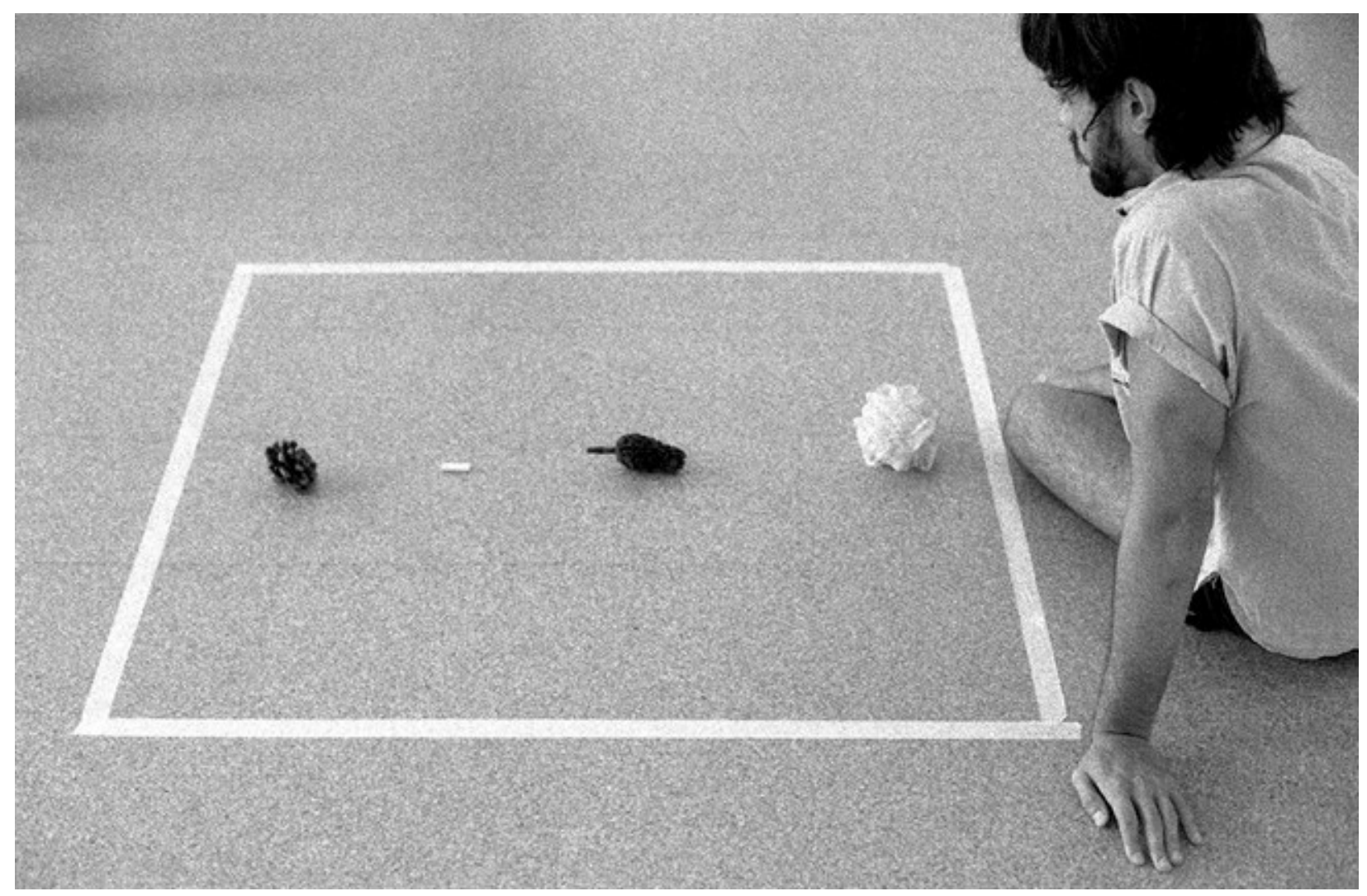

Foto: Filipe dos Santos Barrocas 
A _ Pergunto-me se será possível evitar algum grau, por ínfimo que seja, de manipulação, em todas as circunstâncias. Mas penso, também, que talvez exista uma forma de proteção que nos permita frequentar ou situarmo-nos mais num funcionamento de manuseamento e menos num funcionamento de manipulação. Ou seja, um investimento continuado de auto-regulação, que resulte do treino de um determinado tipo de disponibilidade. Dentro da terminologia do AND usamos frequentemente o termo awareness, que é correlacionável ou pode até mesmo revelar-se equivalente a disponibilidade, que eu proponho tratarmos aqui. Foi através de um texto de Walter Benjamin - intitulado "O Narrador" ou "O contador de histórias" -, mais precisamente através de uma tradução para português, do João Barrento, que cheguei a disponibilidade. Expondo em nota de rodapé a justificação da sua escolha, Barrento decidiu traduzir a palavra alemã Langeweile, não por tédio - como é também habitualmente traduzida para inglês (boredom) - mas por disponibilidade (que não acarreta o sentido pejorativo de tédio). Ao ler esse texto, pareceu-me que, apesar das diferenças, é possível encontrar algumas afinidades entre a atenção/awareness, tal como praticada no AND, e a disponibilidade benjaminiana. Ambas se apresentam como uma espécie de estado, mas também como capacidade ou agilidade, que implica uma relação peculiar com o tempo, uma relação de uso do tempo que joga com a sua elasticidade, esticando-o. Por outro lado, se no AND se treina uma atenção redobrada (e que se desdobra), a disponibilidade benjaminiana, supostamente, depende de uma certa desatenção, desprendimento ou, se quisermos, distração. Aliás, ambas implicam algum tipo de distração, mas são distrações de diferentes ordens. A distração que subjaz à disponibilidade benjaminiana seria a de um certo entorpecimento da consciência, talvez - um estado de relaxamento -, ou, melhor, de uma distribuição da atenção por tarefas outras que não depositam toda a tensão/atenção no ato de ouvir. Já a distração no AND está mais associada, a meu ver, e usando a terminologia própria, a um 'despistar do Eu' (ego), a uma suspensão temporária da condição de sujeito predeterminado. Uma distração de nós próprios, por assim dizer, que é outro tipo de desprendimento dos nossos preconceitos e padrões (etc.), e que só pode resultar do mapeamento de nós mesmos e do entorno. Esse mapeamento faz uso de uma atenção 'filigranar', não meramente de uma desatenção porosa. Finalmente, a disponibilidade benjaminiana aparece associada a uma formação temporária de comunidade - a teia que une o contador de histórias e os seus ouvintes - que se aproxima da experiência do AND talvez mais obviamente na escala do jogo, na coabitação do encontro em busca de um plano comum. Mas para regressar à questão central desta minha intervenção, o trabalho ou treino do Modo AND é de aplicação tão transversal que se pode tornar um modo alternativo de funcionar (em diferentes facetas da vida). Adquirir a capacidade de ativar este outro modo, que não é o predominante, talvez nos proteja, nos impeça de cair na armadilha da manipulação com tanta frequência.

F _ Eu acho que tem uma distribuição da atenção (awareness) - distribuição aqui no sentido de espalhamento e afinação - que vai sendo gerada com a prática continuada do AND. Quase como um alongamento: se se fizer todos os dias, vai-se ganhando espaço articular. Se se deixar de praticar, este espaço vai voltando a encurtar. É bem parecido. A prática do AND, assim como a do alongamento, não muda 
e não pretende mudar as condições ou as tendências que nós temos. Trabalha justamente com essas condições, tanto na sua dimensão tangível de limite como nas suas virtualidades de ilimite. No caso do AND, o alargamento vem da geração de uma maior clareza sobre as condições de cada situação, corpo, encontro etc. - o que eles potenciam e o que não e, dentre as potências que lá estão, quais estão ativas, quais são tendências minoritárias, quais são aquelas que se organizaram em padrões viciados que, eventualmente, até podem estar a encobrir outras potencialidades. A prática da atenção constante, essa frequentação persistente do problema do encontro, com as suas recorrências e as suas diferenças emergentes, vai explicitando as tendências de cada praticante. Esta explicitação, por sua vez, permite que aquilo que poderia ser um padrão fechado e recorrente se disponibilize como matéria, abrindo-o, desfragmentando-o, fractalizando-o. Essa zona da prática do Modo Operativo AND - a zona que vai do re-parar ao reparar, ou seja, do acknowledgement à awareness - é uma zona de treino da atenção antes do fazer. É toda uma zona de 'pré-ação'. Ou, mais precisamente, de entre-ações, de intervalo entre uma posição e outra. Neste sentido, é um trabalho que acontece num plano ainda sem efeito e, portanto, completamente 'sem caráter': ainda não se sabe que uso posterior vai-se dar a esta capacidade de atenção alargada ou a materialidade que ela disponibiliza. Isso só se vai definir quando a pessoa agir, tomar uma posição. Este treino prepara e convida a que esta posição seja uma posição-com - e não uma imposição - mas não garante por si só que assim seja. Há depois mais a trabalhar, a fim de sustentar a atenção filigranar enquanto distração do ego - e não dispersão porosa apenas - permitindo assim uma tomada de posição ética e suficiente.

A _ Por isso é que gosto também da palavra disponibilidade, além da palavra atenção. Porque, para mim, disponibilidade, de certa forma, encerra em si o potencial para o desdobramento. Claro que podemos falar em práticas de atenção ou numa prática de atenção continuada mas, se atendermos só às palavras isoladas - atenção e disponibilidade -, atenção parece-me algo mais transitório, que acontece dentro de um enquadramento espácio-temporal apertado, e a disponibilidade uma coisa que se expande, que não está circunscrita a esse enquadramento espácio-temporal mas que, se quisermos, tem início nesse ponto originário de atenção mas que continua, que persiste. Talvez aqui seja interessante também introduzir outro termo de articulação que é o de latência. Num certo sentido, é como se a disponibilidade fosse uma espécie de capacidade, que se adquire e fica latente, permitindo ativar ou reativar essa atenção específica.

F _ Sim, talvez seja possível descrever o processo de reparagem proposto no MO_AND distinguindo uma camada mais ligada à geração da atenção e uma outra já caracterizada pelo ativar e frequentar da disponibilidade. Mas não sei, talvez essa zona intervalar do 'antes do fazer' ou do entre-fazer que eu estava descrevendo já seja feita disso tudo, inclusive sob a forma da latência. Porque nesta parte do trabalho, o treino do reparar permite ir explicitando aquilo que está lá disponível como matéria e, convocando a sensibilidade a funcionar numa lógica mais espalhada, mais disseminada, em que o entorno é levado sempre em consideração, numa espécie 
de scan detalhado do que há, que está em constante reinventário e recontagem dos possíveis, conforme as situações se vão reconfigurando. Essa zona, pode-se dizer, é onde se pratica a própria awareness e eu acho que ela, pelo menos em latência, é já inevitavelmente disponibilidade. Como disse, isso não quer dizer que esta disponibilidade será mesmo exercida e sustentada quando se passar à tomada de posição. Pois existe também esta outra zona do trabalho, que envolve entrar em acontecimento com o outro, cujo desafio tem a ver com o que se faz com a matéria que o treino da atenção-disponibilidade proporcionou inventariar. Aí é que se vai colocar propriamente a questão ética de permitir que a disponibilidade saia do estado de latência ou não. O treino da atenção propicia a disponibilidade - essa capacidade de disseminar e distribuir a atenção, de despistar as vontades do eu ocupando-se com as vontades da situação. Mas, a seguir, a disponibilidade só termina de se efetuar se o agir tender ao manuseamento e não à manipulação - o que não é propriamente uma diferença de natureza do gesto, mas de grau de interferência, pois tanto para manusear quanto para manipular é preciso inevitavelmente intervir, e para ambas é preciso também uma clareza muito grande do que há. É claro que existe um outro tipo de manipulação, mais emocional, talvez, que é quase o oposto desta manipulação perversa do expert ou do 'super-autor'. Um tipo de manipulação mais desligado da capacidade de atenção, que se configura quase como um vício identitário ou do já-saber, e que acontece precisamente por desatenção e indisponibilidade: teria a ver com o jogo de papéis marcados, uma lógica de barganhas, quase com uma pequena sordidez que desponta quando se julga conhecer bem o outro e já saber que "se eu agir desse modo, se eu apertar ali aquela pessoa, ela vai ceder e me dar o que eu quero".

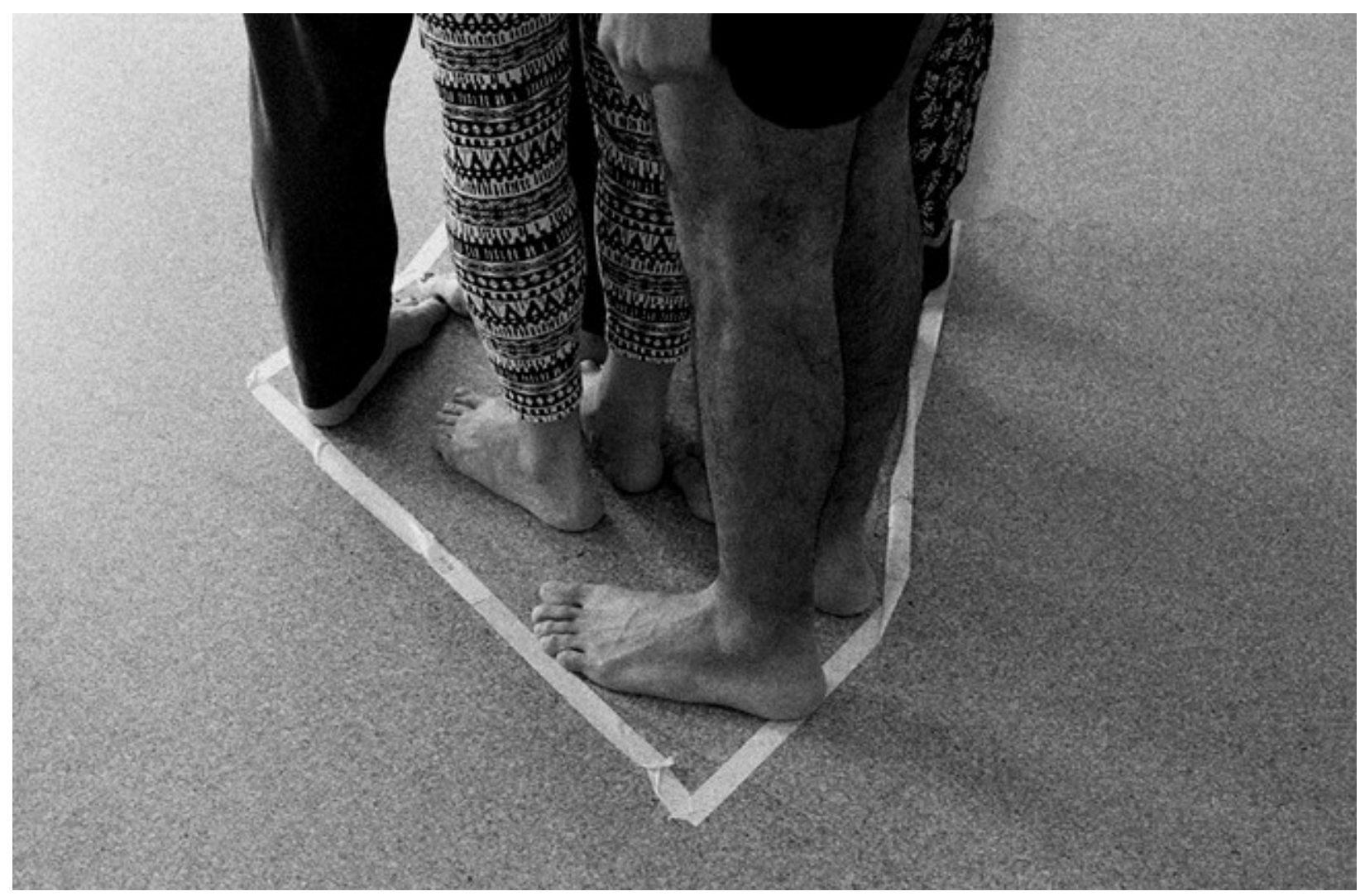

Foto: Filipe dos Santos Barrocas 


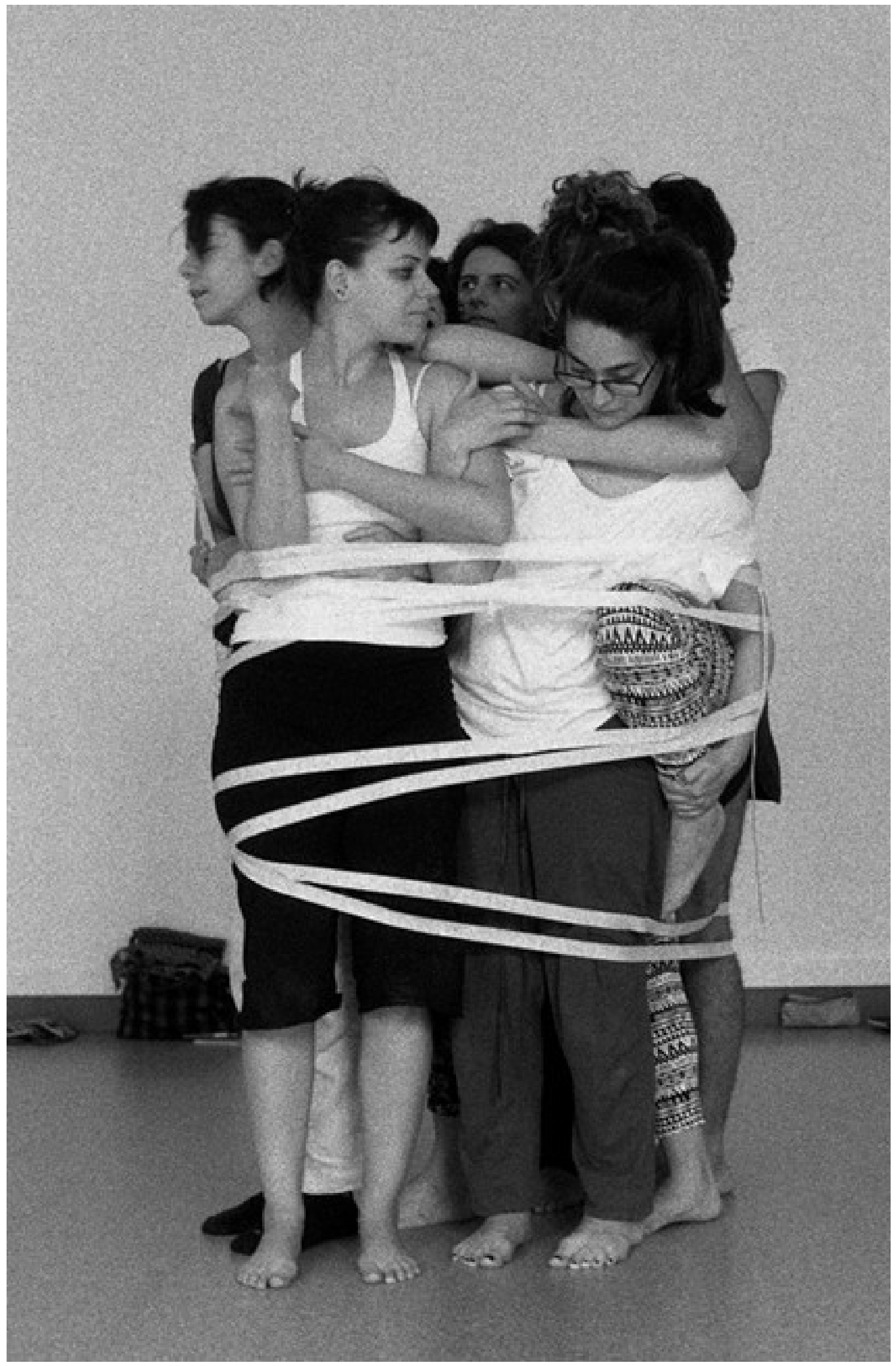

Foto: Filipe dos Santos Barrocas 


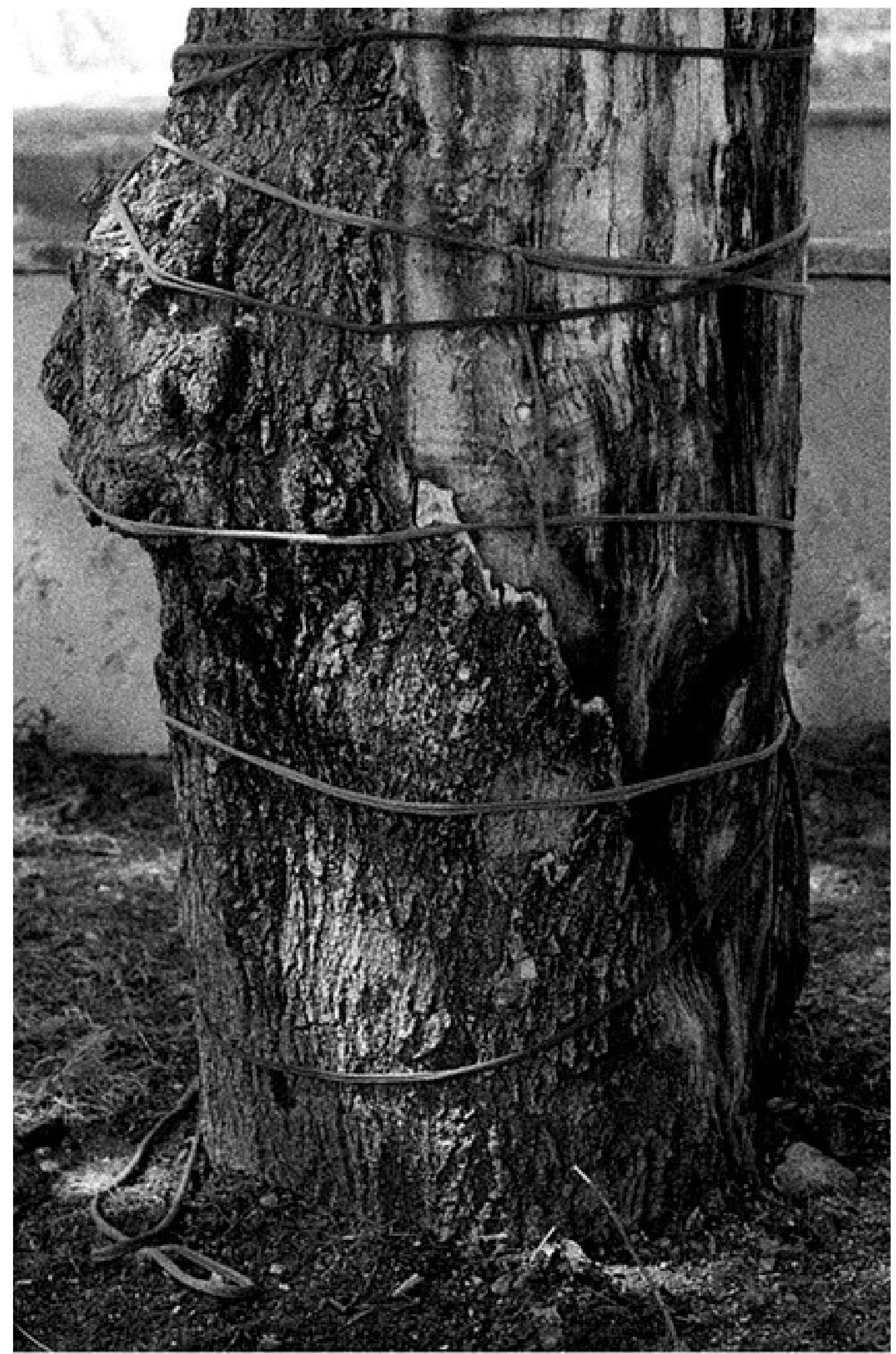

Foto: Filipe dos Santos Barrocas

Milene Lopes Duenha 
A _ Esse intervalo entre uma disposição para mapear e as consequências desse mapear na posição que se toma pode ter uma correspondência com o intervalo entre uma estética que se adopta e a ética a ela acoplada. Diferentes estéticas podem resultar da adopção de uma ética de manuseamento ou de uma ética de manipulação, obviamente. Mas, por outro lado, pode acontecer que uma determinada estética indique o recurso a um determinado posicionamento ético que não é efetivado. Ou seja, uma certa ética é sugerida por um resultado estético mas sem que haja propriamente uma correlação. Em resumo, pode dar-se o caso de uma determinada estética resultar de uma determinada ética e haver um encaixe, um ajuste ou um encontro, mas o oposto, um falso encaixe, um desajuste ou um desencontro, também é possível.

F _ Várias vezes o Modo Operativo AND é referido como uma ferramenta ético-estética. Talvez, em algum momento, tenha sido eu mesma a formular as coisas assim; hoje já não uso muito essa formulação. Parece-me que bastaria sublinhar que o AND é sobretudo um ferramenta para o funcionamento suficiente: a suficiência é a sua ética. Ela tomará, sempre e a cada vez, uma forma; daí por consequência vir a ser também uma estética. Mas não se começa por um primado estético de nenhum tipo. A ética da suficiência pode vir a pedir por movimentos minimais, precisos e pontuais ou pelo extremo oposto, movimentos elaborados, complexos, cheios. Por isso, talvez seja mesmo importante ressaltar que esta ordem - ético-estética e não estético-ética - faz toda a diferença. Esta sequência sinaliza uma direção: começar por uma ética, chegar a uma estética por consequência. Sinaliza também o que está a ocupar o lugar de funcionamento ou força, e o que está a ocupar o lugar de forma, aparência, aparição. Isto tem a ver com o que estávamos falando há pouco, sobre o que acontece depois da atenção ser gerada. Depois de se passar por um trabalho de reparagem, de rastreamento e de inventário do que existe e está disponível no momento - seja nas minhas próprias habilidades, na esfera do meu corpo, do meu imaginário, dos meus afetos, seja no que está em meu redor, seja ainda no plano dos colaboradores com quem eu convivo etc. - existe então uma entrada em relação. E como é que se dá essa entrada em relação? Ela pode se dar pela via do manuseamento, o que implica que essa entrada em relação vai procurar a suficiência do gesto e a menorização do Eu numa mínima condução das coisas - ela não toma a frente, não lidera, não conduz os materiais, não faz os materiais passarem pelos seus desejos, manipulando-os; mas, ao contrário, procura interrogar quais são os desejos dos materiais e se colocar a serviço deles e dos acontecimentos. Essa decisão - que será, na prática, uma descisão - é que é a entrada em ética. Porque o primeiro trabalho que tem a ver com mapear o que é situadamente possível, o que está disponível de modo contingente e acidental - essa zona, embora já pertencendo, em latência, a uma ética, não assegura por si só um funcionamento ético, não o garante. O fato de se ser capaz de escrutinar tudo o que está aqui disponível de modo franco e não-interpretativo não assegura que, a seguir, não se utilize este inventário filigranar justamente como 'munição' para manipular. É uma capacidade, de fato, importantíssima, mas que pode ser posta, depois, ao serviço de um funcionamento primeiramente estético e não ético. Então, o momento em que sabemos se estamos num trabalho ético-estético ou estético-é- 
tico - ou só estético, até, porque o ético neste caso corresponderia apenas a uma forma ou aparência, não a uma operação - é aquele momento em que passamos ao ato. E como fazemos isso? Como entramos em relação? Como damos corpo a todo esse esforço cartográfico que aconteceu, que foi a prática atenta do inventário? Se acontecer desse mapeamento todo depois ser posto ao serviço de um 'eu quero', 'eu acho', 'para mim é assim' ou 'eu tive uma ideia', não se começará pela ética, mas pela estética. A forma tomará o lugar do funcionamento, numa inversão perversa, pois pode ser até que, no produto final, a gente não a consiga reconhecer - aliás, a manipulação bem-feita tem mesmo essa componente perversa de esconder-se muito bem, se tornando indemonstrável - se tornando implícita. Enquanto o manuseamento, ao contrário, trabalha sobretudo num plano de explicitude, sendo sempre rastreável e acessível - é possível seguir o seu desdobrar. Mas se o que se ativa na entrada em relação é um funcionamento estético, o que se passa é, sub-repticiamente e por antecipação, haver o privilegiar de uma zona de questões - aquelas que povoam o imaginário do autor. Ao invés da entrada em relação se dar por des-cisão, ela se dá por decisão: uma decisão que é tomada de antemão e, depois, dentro da matéria que foi inventariada, isso levará a se ir fazendo uma espécie de casting do que pode e do que não pode entrar, de que corpos combinam com aquela ideia e que outros não podem entrar porque não lhe interessam. Poderá haver, por exemplo, a escolha do corpo esguio, ou do corpo veloz e ágil, do corpo destemido; e o descarte tácito dos corpos que não podem fazer o que quer e prescreve o imaginário do autor. A depender de que imaginário estético for este - se for, por exemplo, um imaginário minimal ou formalista - até pode ser que a obra ou o trabalho resultante desse funcionamento assuma uma aparência similar a um funcionamento ético, sendo que será mesmo só isso: uma similaridade formal. Pois isto de ter corpos eleitos, por exemplo, seria impensável num funcionamento ético-estético, que trabalha por des-cisão, com os corpos incidentes na relação sejam eles quais forem. Neste funcionamento, serão os corpos - e o que eles puderem ou não oferecer à relação e, depois, o manuseamento dos modos como eles se podem suficientemente conectar e desdobrar - que levarão a uma estética emergente. Uma estética, portanto, sem imaginário de autor; sobre a qual ninguém legislou de antemão.

A _ Talvez possamos pensar na questão do efeito. Porque nós temos vindo a pensar muito no afeto mas menos no efeito, ainda que pensemos em consequência(s). Em inglês, effect e affect são muito próximos, o que dá azo a imensas confusões, algumas até bastante profícuas. Em português nem tanto, afeto e efeito diferem em mais do que uma letra. Aqui, talvez possa ser interessante reformular a questão anterior, fazendo uso do termo efeito. Uma determinada estética pode ser, efetivamente, resultado de uma postura ética e de um procedimento seguindo essa mesma postura, e então existir uma correspondência, mas também pode acontecer o oposto, ou seja, o efeito pode não assentar numa correspondência mas numa qualquer coincidência.

F _ Enfim, as coisas para acontecerem é porque tomaram forma. Elas se per-formaram. Performar, uma das maneiras pelas quais podíamos abordar isso, seria esse 
fazer-forma ou entrar-na-forma. Envolverá sempre um gesto, uma tomada de posição de um agente, um fazer. Mas há doses, diferentes gradações de interferência, que poderemos distribuir num continuum que vai do manuseamento suficiente à máxima manipulação e desejo de controle. Performar pode, na sua mínima versão, ser quase só cumprir uma potência que já lá esteja naquilo que foi mapeado e, então, quase que esse per tem uma dimensão de perfazer, de percorrer, de circundar ou circunscrever para, por adensamento, juntar-se ao formar - e assim efetuar e dar corpo... Se assim for, aquilo que se per-formar será aquilo que precisar acontecer, o que for mais justo na relação com o que já lá estava. E o ato será menor, menorizado em autoria. Ou seja, sem a imposição de uma direção que venha, por exemplo, de um repertório estético em particular. Em vez disso, será uma escuta disponível às condições e fatores de situação, um deixar-se afetar pelo que é possível e preciso a cada vez - será isso que irá disparar o processo da per-formance. Um trabalho a partir dos afetos e desapegado de controlar os efeitos explicitará e acentuará um funcionamento que começa por percorrer o problema, por entrar em co-passionamento com o alheio e, só depois, e porque se cumpriu enquanto percurso (sem saltar etapas, sem pressupor, mas indo de posição em posição, de perto em perto), chega a performar qualquer coisa. Chega à forma; não já começa por ela. Chegar à forma será o mesmo que dizer: chegar a uma estética emergente de uma ética. É óbvio, porque quando se entra em acontecimento é porque também se entra em forma: aquilo tudo que era força se instancia, se performa. Mas se estamos a praticar uma ética da suficiência, o desejo de controlar essa forma final dá lugar a um engajamento no próprio dobra-desdobra relacional, a uma afetação sustentada, que vai cuidando dos efeitos emergentes, sem se ocupar de gerar, ela própria, qualquer efeito. Porque não é preciso 'causar' - e nem há tempo ou espaço para isso - quando se está dedicado ao consequenciar dos acontecimentos. 


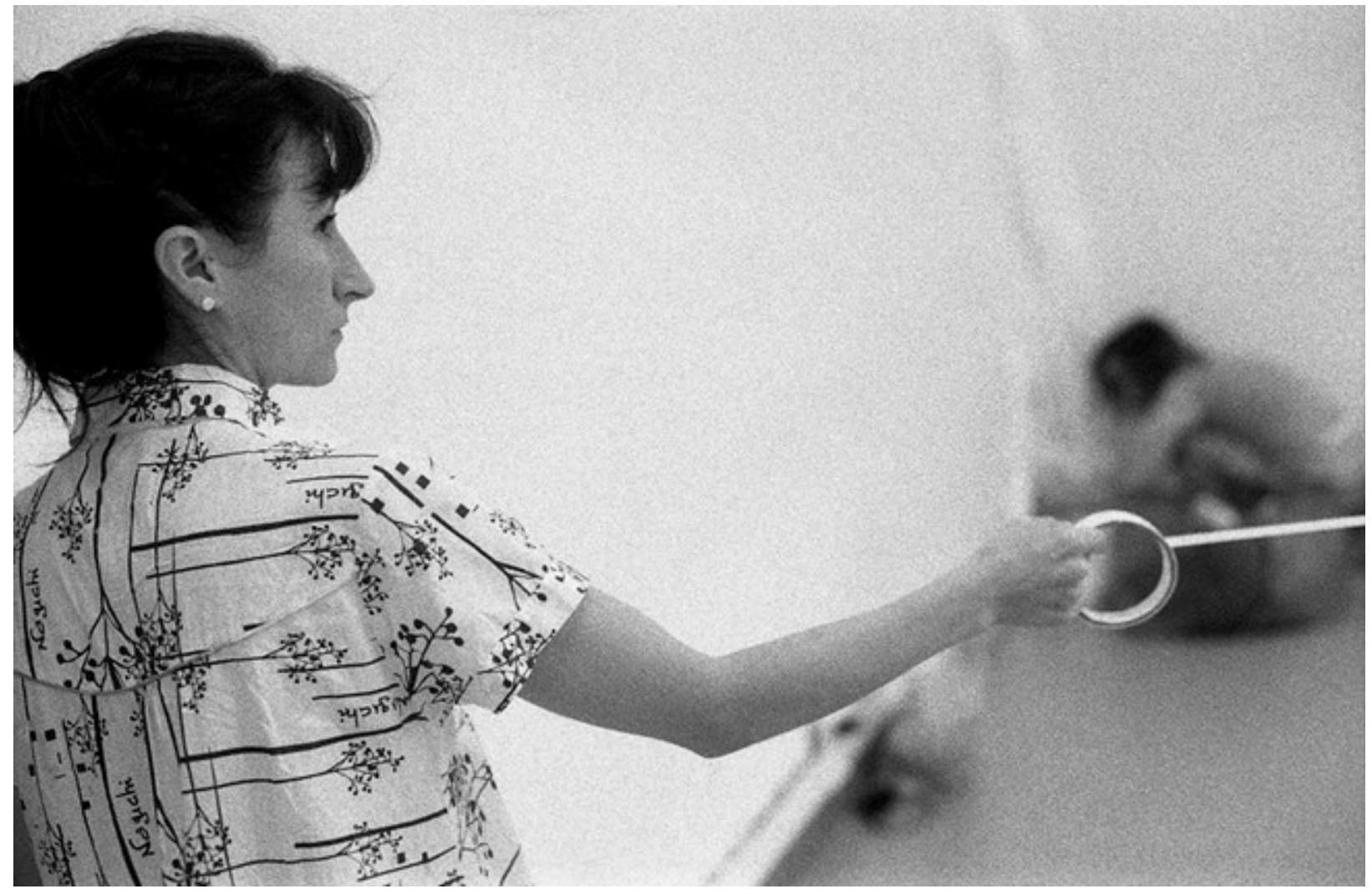

Foto: Filipe dos Santos Barrocas

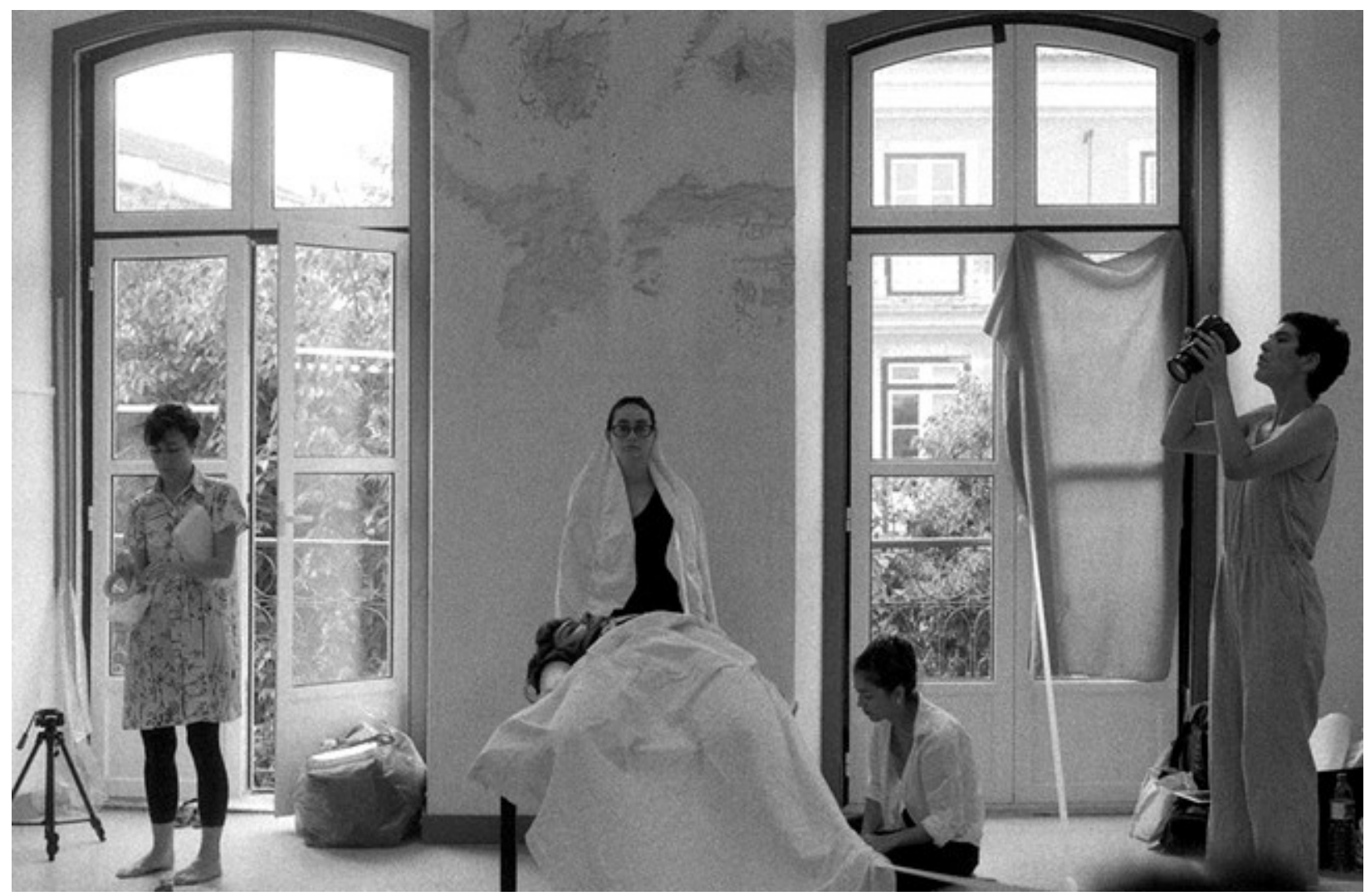

Foto: Filipe dos Santos Barrocas

Milene Lopes Duenha

Fernanda Eugénio 
A _ Essa questão de abdicar de controlar a forma em detrimento de um engajamento com as relações emergentes fez-me pensar na arte engajada. Ultimamente, temos assistido a um reforço ou insistência na defesa de que a arte deve ser engajada. Que, nos tempos que correm, com todos os males que assolam este mundo, a arte já não pode ser algo de desinteressado, algo de alienado, algo que só se serve a si mesmo, enfim, todas as formulações que servem o argumento. Estou a falar de uma defesa de economia de meios, nomeadamente, como contraste à capitalização ou mercantilização voraz da arte. Se, por um lado, esta última direção pode ser problemática, levando a uma arte domesticada, inócua, indiferente ou até mesmo ecológica e eticamente discutível, por outro, o que acontece com a arte que procura ser engajada é que cede frequentemente às vicissitudes inerentes à tematização redutora, defendendo uma agenda própria ou ficando refém de outras agendas externas (agendas defasadas do problema). Enfim, uma arte que cai no sobre - não no a-respeito-de mas no outro sobre, com tendências mais manipuladoras, muitas vezes a despeito-de. Corre o risco de sucumbir, como já te ouvi dizer, ao enrijecimento do que poderia ser um funcionamento ético num funcionamento moral(ista). Então, eu pergunto-me se não é limitativo e perigoso apelar a que a arte seja sempre da ordem do engajamento ou mesmo do ativismo. Porque, para mim, qualquer sentença de 'tem de ser' pode ser entendida como manipulação. Mas também urge pensar no que se considera engajamento. Talvez convenha não fazer equivaler engajamento a arte engajada. Eu sinto que há uma postura ética do AND que se tem vindo a tornar cada vez mais necessária na escala do quotidiano mas também me interessam muito os desdobramentos do uso do AND no campo artístico. Em ambas as escalas é, sobretudo, um compromisso de implicação e de responsabilização que me afeta. O trabalhar contínuo e constante para estar à altura do acontecimento. Essa escolha tem uma dimensão política. E é transversal, o que me leva à tua decisão - ou consequência de 'des-cisão' - de exercer a etnografia fora da academia. Um modo, método, ferramenta ou conjunto de ferramentas, ainda que possam alimentar certas disposições, não são necessariamente nem garantias nem obstáculos. Diferentes usos, talvez mais do que as molduras que os enquadram, acarretarão diferentes consequências.

F _ O Modo Operativo AND ganhou finalmente esse nome nos anos recentes mas ele não é diferente da etnografia, em particular de um certo modo de fazer etnografia que em algumas épocas chamei de etnografia recíproca, noutras de etnografia performativa, noutras ainda de etnografia como performance situada. Esse modo de fazer emergiu, primeiro, contra o pano de fundo do campo antropológico, emergiu como um imperativo crescente que fui sentindo em levar a sério a vivacidade da experiência do encontro etnográfico, a dimensão de performatividade e invenção recíproca que estão em jogo ali, e que quase sempre tendem a sucumbir quando se passa ao plano da análise, da construção da coerência explicativa ou interpretativa do outro. Percebi logo, em especial durante o doutorado, que precisava mesmo de tirar as consequências disso, de permanecer no problema com rigor e franqueza: o campo do meu doutorado me confrontou com a necessidade de invenção de conceitos-ferramentas, conceitos que pudessem não só ser ditos mas também feitos, efetuados, colocando num mesmo plano aquilo que eu poderia defender em termos 
de pensamento e aquilo que eu era capaz de fazer. Foi ali que formulei pela primeira vez o AND - na época o chamei de 'estilo de vida $E^{\prime}$ - enquanto funcionamento transversal, de regras imanentes. Fiz isso num esforço de pensação, de concretizar conceitos, ou seja, desfragmentá-los, fazê-los passar ao plano do uso e do funcionamento: fazer com os conceitos e conceituar com o fazer. Diversos outros encontros e situações contingentes concorreram para que, lentamente, de uma conversa meio "endógena" com o campo antropológico, o pensamento do AND fosse se autonomizando como uma ferramenta transversal, um fazer do comum, um modo de estudar o funcionamento das relações, as consequências dos nossos gestos, os modos do acontecimento e da convivência. Acho que o AND ter-se organizado enquanto prática, modo operativo, é, em grande parte, consequência não só de uma tomada de posição em relação a problemas bastante concretos da antropologia, mas do fato de eu ter passado longos anos a ser professora de primeiros períodos na graduação. Isso me confrontou com a questão, por um lado, de que a etnografia é 'inensinável' e de que, por outro, não se pode desistir. Geralmente é o que se faz, desiste-se do campo ou mitifica-se o campo como uma experiência a se ter "um dia, mas não agora". E ensina-se uma antropologia estritamente conceitual, que mesmo assim tem uma grande eficácia em arejar a cabeça das pessoas, mas que se ficar só no plano conceitual pode não passar de discurso, um politicamente correto relativista sem consequências no modo como se vive e se convive. Foi nesta fase, por exemplo, que emergiu o exercício prático, ainda hoje um exercício central para ativar a reparagem no MO_ AND, de passar do porque ao como, enquanto chave para praticar o não-interpretar, para desviar da tentação de atribuir significado e se concentrar num trabalho minucioso de descrição-circunscrição do que acontece, como acontece, quando e onde acontece. Praticar insistentemente um certo tipo de etnografia, aquela que assume que quase tudo ou tudo que vai vir a ser o seu trabalho de investigação acontece ali, naquele encontro, no modo como se posiciona, no modo como se negocia, e depois no que emerge entre as pessoas, numa espécie de co-posicionamento ao vivo, trabalho de mapeamento recíproco e de povoação lenta daquela relação entre você e aquele outro mundo com o qual se decidiu entrar em relação de empatia... foi isso que me levou a esbarrar depois nos dois grandes outros encontros que são chaves para o AND ter tomado (e estar sempre re-tomando) o corpo que tem hoje. Por um lado, o encontro com o campo da dança e da performance - e, junto com ele, com o dispositivo do laboratório e do estúdio, um recurso que não existe na antropologia, e que traz a possibilidade de jogar com as escalas de um modo muito mais experimental, sem ainda as consequências radicais do encontro em escala humana. Por outro lado, e ainda mais recentemente, o encontro com os campos psi, em especial com os modos de fazer da clínica transdisciplinar praticada no Brasil, que tem entrado em conversação de forma muito potente com toda uma dimensão da minha pesquisa ligada à performatividade do afeto. 


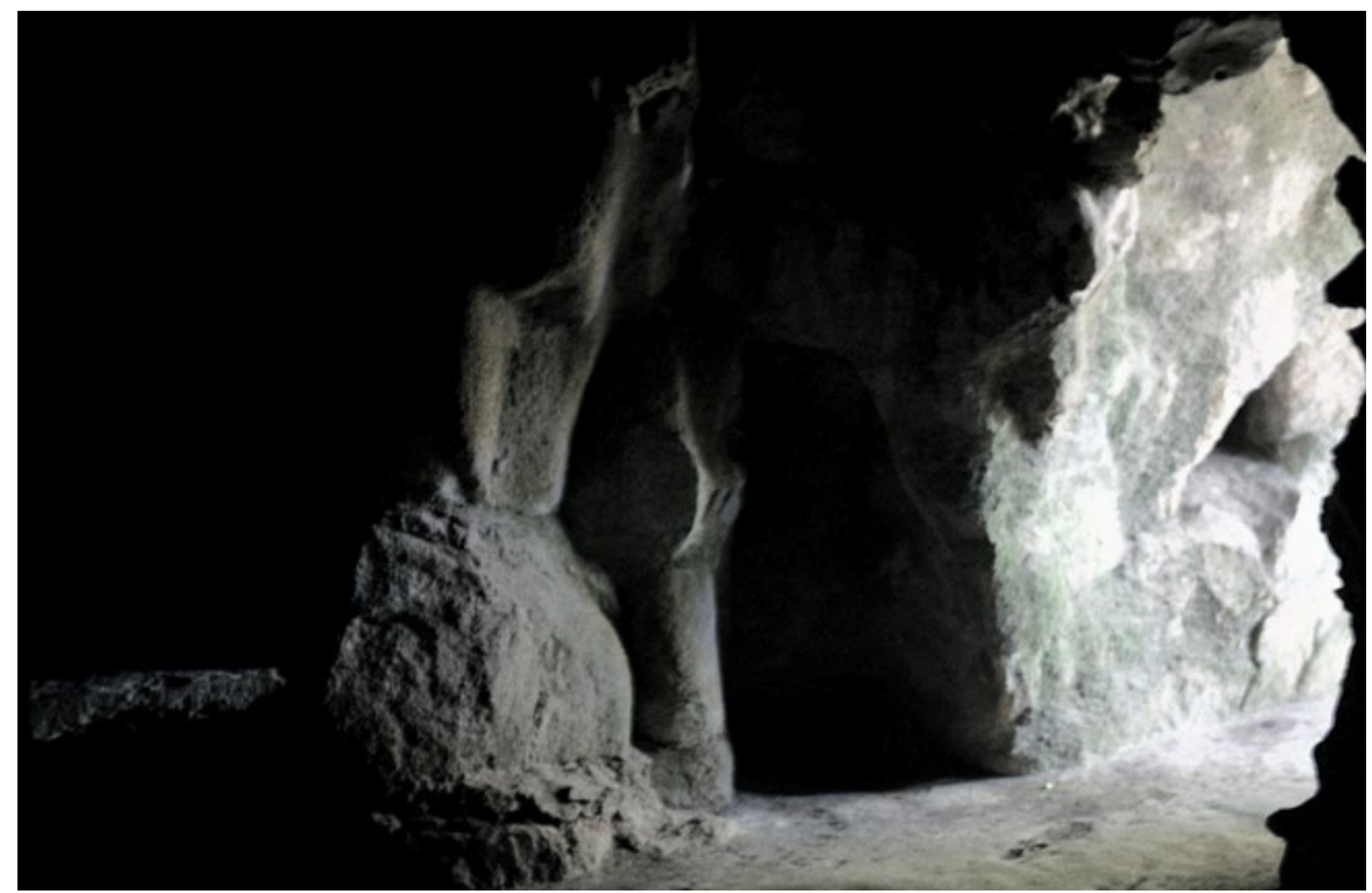

Foto: Filipe dos Santos Barrocas

A _ O AND, sendo alguma coisa a que as pessoas podem ou não aderir, e havendo adesão, varia ainda na forma como as pessoas o trazem para as suas vidas e o adaptam, que uso lhe dão, o quanto se entranha. De certo modo, podemos dizer que o AND tem angariado seguidores. Há grupos que se reúnem regularmente para uma prática partilhada, há investigadores, artistas, artistas-investigadores e investigadores-artistas, enfim, pessoas vindas das mais diversas áreas e com as mais variadas trajetórias que encontram diferentes formas de articulação (aplicação, transposição, reajuste, etc.) entre as suas práticas, as suas inquietações, as suas ocupações e o AND. Talvez se possa dizer que há uma espécie de comunidade emergente - que não corresponde às formações temporárias permitidas pelo dispositivo jogo de que falei acima, que está além, num outro plano -, a que eu às vezes apelido afetuosamente de AND_people, numa referência ao Fahrenheit 451, do Ray Bradbury, em que um grupo de pessoas - book people - memoriza livros ou trechos de livros proibidos num futuro distópico, assegurando a sua continuidade através de uma relação metonímica. É, novamente, de responsabilização e compromisso que falo e, desta feita, é do compromisso com a duração que proponho tratar. O tempo que cada um se permite de contato com o AND, o tempo que se dedica ao treino, a frequência com que se regressa aos workshops, o grau de infiltração no quotidiano. O AND ser algo em que se insiste e que assim subsiste e persiste. Diferentes graus de abertura, entrega ou investimento têm diferentes consequências. A relação ser duracional é importante.

F _ Sim, de fato a prática ser duracional é importante, porque o trabalho que leva mesmo tempo é o de desativar ou pelo menos suspender um pouco os funcio- 
namentos com o quais se chega - a uma oficina ou workshop, mas também a uma nova relação. São funcionamentos habituais que muitas vezes operam por desatenção, à nossa própria revelia, e que, sendo muito diversos, são variações de um modo operativo 'é', pois estão definidos à partida, ao invés de se construírem em relação. Por isso precisamos de alguns dias, nos workshops; não porque a prática que está se propondo ali tenha um grau de complexidade absurdo, ou um repertório a se assimilar, já que o MO_AND não é uma técnica, não tem conteúdos preestabelecidos: precisamos de tempo justamente porque não tem nada para aprender. Tem é um trabalho de desaprender: reconhecer, desautomatizar, desacelerar e menorizar certos funcionamentos. Eu até acho que este tempo não é assim tanto - uns dias de prática para sintonizar com outra faixa de frequência? - se considerarmos a pujança do 'é', o quando ele é pervasivo e dominante, o quanto o nosso entorno e as nossas relações, do micro ao macro, estão organizados em modo de predeterminação das regras, de modelos, expectativas e cobranças, de certos e errados, de permissões e interdições a priori etc. Mas uma coisa é conseguirmos, no espaço-tempo de uma oficina, colocar o 'é' entre parênteses, gerar coletivamente um "platô", uma 'zona autónoma temporária'. A outra tem a ver com o construtivismo permanente necessário para se continuar a praticar o 'e' a cada vez, num plano de extensividade. Acho que é sobretudo por conta disso que precisamos de um trabalho na duração. Porque, num certo sentido, este é um trabalho interminável: ninguém consegue se tornar, finalmente, um perito em AND, um especialista, alguém que incorporou aquilo de tal maneira que vira o seu funcionamento automático. O MO_AND é justamente um desautomatismo, é um trabalho sobre não-saber. E nunca se acaba de não-saber. Por isso, se ele se automatizar, deixa logo de ser "e" e se torna numa das muitas faces do "é". Quando muito, creio que isso pode acontecer no plano laboratorial, quando de tanto praticar gera-se um domínio muito grande dos materiais, o que pode dar azo a uma espécie de 'zona de truque', de 'pseudo-expertise' - é pena, porque cai-se de novo na tentação de já saber. Aliás, eis aqui um bom modo de visualizar aquilo de que estávamos falando há pouco: como se pode se ir enrijecendo numa estética minimal-racional ou racionada - apenas formalmente parecida com uma ética rigorosa da suficiência. Persistir na duração vai revelando que a suficiência é algo a se trabalhar inevitavelmente a cada vez, pois a relação, o encontro, o acidente, nunca fazem problema para nós do mesmo modo, mesmo quando se repetem. A cada vez que se re-instanciam, colidem conosco em diferentes alturas, as circunstâncias são sempre contingentes, e portanto também o que se disponibiliza como matéria é diverso, o possível e o impossível não param de ganhar e perder doses fractais, de se reorganizar. O inventário precisa ser constante, considerando que a disponibilidade das coisas, das pessoas e das situações é flutuante. A cada vez, é preciso refazer os modos, reconstruir situadamente o caminho justo para parar, re-parar, reparar, e depois ainda manter uma lógica de reparação que irá permitir sustentar a relação. É tão frágil; a qualquer altura do processo, pode 'desandar'. Ter conseguido antes não dá prerrogativas a ninguém, não assegura que se vai continuar a conseguir. É também por isso que o MO_AND é uma investigação interminável: o que faço é, sobretudo, partilhar perguntas e um conjunto de exercícios e práticas que foram se afinando por frequentação insistente, mas não tenho nada a ensinar. E de fato, como na comparação que você faz com 
as "pessoas-livro", as "pessoas-AND" modulam e reformulam o AND à sua maneira, metonimicamente, sendo este processo contínuo a própria forma de propagação e reinvenção do AND, permitindo que o sistema esteja sempre se "sistemando" e se "assistemando" ao mesmo tempo, se pondo em questão, se reperguntando. Quando estamos em modo oficina - juntos ou separados por um oceano - estamos ajudando uns aos outros a continuar a desaprender, a partir do manuseamento de matérias suficientemente quaisquer para que possamos investir toda a nossa atenção em tornar explícito o funcionamento dos acontecimentos que somos, e também daqueles acontecimentos que se dão entre nós.

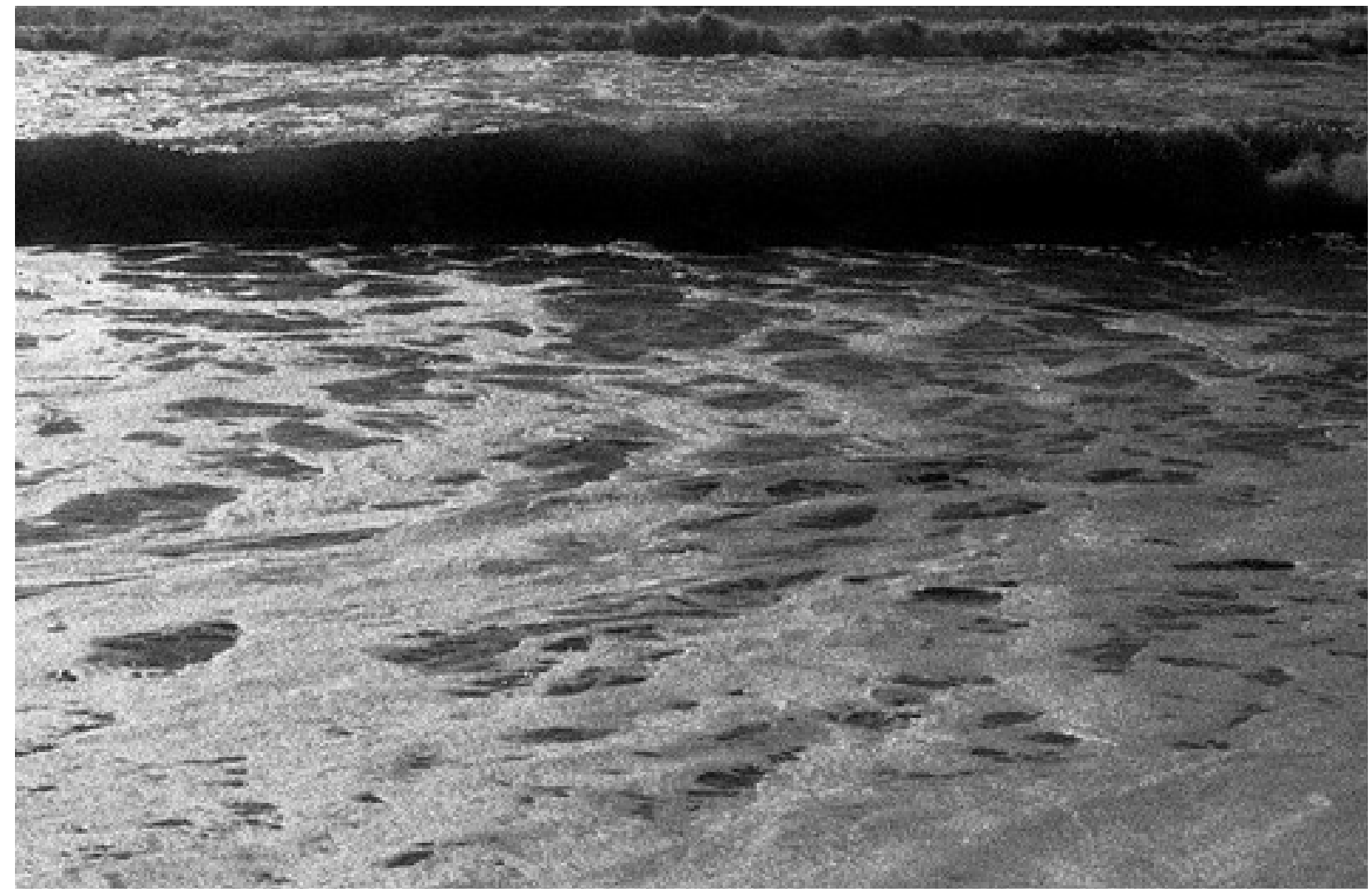

Foto: Filipe dos Santos Barrocas

A _ Fazer do quotidiano laboratório e do laboratório quotidiano. Estava aqui a pensar se esta formulação consegue abarcar as várias escalas que o AND atravessa. É porque a transversalidade permite pensar que tudo é passível de se tornar matéria, da mais micro à mais macro das situações, do mais interno e singular acontecimento ao mais partilhado e co-constituído encontro com outros. Nesse sentido, o quotidiano, seja qual for o recorte de análise que lhe apliquemos, pode a qualquer momento tornar-se laboratório, ao ativarmos este modo alternativo de 'entrar em relação'. É claro que aquilo que estritamente chamamos de dispositivo de laboratório ou estúdio é já um recorte, também, deste quotidiano. Por outro lado, o 'fazer do laboratório quotidiano' seria uma possível forma de enunciar o AND como essa prática laboratorial continuada, constante, seja em que escala for. Seja na escala maquete, o que nós temos vindo a associar a uma prática laboratorial, de estúdio, seja a escala vida, que temos vindo a associar ao quotidiano. 
F _ Sim, o frequentar quotidianamente o laboratório, em diferentes escalas, é crucial para se sustentar uma espécie de trégua com o modo operativo 'é', para adensar por infiltração lenta a brecha do 'e'. Não será jamais possível - e nem é desejável - se tornar um virtuoso, mas ainda assim a frequentação constante vai desenhando uma capacidade de sintonização ao mesmo tempo mais alargada e mais imediata. "Fazer do quotidiano laboratório e do laboratório quotidiano", como você sugeriu, permite ir reconhecendo de um modo cada vez mais franco que, seja em que escala for, tudo é matéria, diminuindo o 'pessoalismo' com o qual costumamos dividir as coisas por critérios de identificação do tipo 'gosto, não gosto', 'combina comigo ou não', 'quero, não quero', 'me convém ou não me convém', e abrindo espaço e tempo para ir-se alastrando um modo mais impessoal e equânime de se distribuir as coisas, acolhendo as doses em que se apresentam e as inclinações que manifestam, independentemente dos desejos e intenções pessoais. Esse trabalho continuado, seja em que escala for, é bastante ajudado por aquilo que no MO_AND acabou por ficar conhecido como escala maquete, o jogo de improvisação da convivência e de construção coletiva de paisagens comuns praticado numa proporção reduzida, recorrendo, por um lado, à delimitação do espaço a uma superfície pequena que funciona como tabuleiro e, por outro lado, a materiais que costumamos classificar como 'objetos'. Esta nomenclatura de 'maquete' foi muito usada nos tempos em que colaborei com o João [Fiadeiro], mas merece ser repensada. Parece-me que seria muito mais preciso e esclarecedor chamá-la de escala lupa, pois a operação em causa nesse jogo não é a de redução e modelização, de representação em miniatura do mundo mas é, ao contrário, uma operação de multiplicação (gerar mundos dentro do mundo, visibilizando a fractalidade já presente nos nossos mundos) e de ampliação (das inclinações do acontecimento, das dobras da relação, das tendências das coisas e pessoas). No jogo AND, os agentes estão sempre à medida do território e a paisagem emergente nunca representa algo aquém ou além da escala em que acontece. O que me parece interessante é perceber que, no plano laboratorial do estúdio, tornou-se possível propor exercícios de posição-com-posição baseados na redistribuição das doses, seja do espaço seja do tempo. Há um conjunto de exercícios que exploram a correspondência entre redução do espaço e dilatação do tempo e todos eles, poderíamos dizer, perfazem juntos o dispositivo da escala lupa. O jogo com fotografias de situações urbanas, que permite desdobrar o tempo de enunciação do afeto ali presente para muito além do instante da captura da imagem, é um deles. O jogo de tabuleiro é outro. Ele é ativado através da delimitação de uma zona de atenção partilhada num espaço restrito da sala - com fita crepe no chão ou usando uma superfície como o tampo de uma mesa. Mas, ao reduzir o espaço, o que estamos efetivamente a fazer é ampliar o tempo de que dispomos para investigar o acontecimento que ali se vai desdobrar, para conversar à volta dele, para dar corpo concreto à conversa e à exploração prática das diferentes consequências de uma tomada de posição. Há, ainda, uma ampliação microscópica que nos permite acompanhar dobra a dobra os movimentos que vão, lentamente, fazendo emergir uma com-posição. Assim, esta escala lupa em laboratório simula, num certo sentido, a experiência da duração etnográfica - suspendendo, entretanto, a velocidade e a irreversibilidade das consequências características do jogo da convivência à nossa escala. Na etnografia a dilatação do tempo corresponde 
sobretudo a uma disposição para a relação imersiva, a insistência no comparecimento, a negociação da própria presença por infiltração lenta. Mas, como ela se joga já diretamente na escala da vida quotidiana, cada tomada de posição é desde sempre definitiva e se tornará condição das posições seguintes - como, aliás, se passa nas nossas demais relações de convivência, íntimas ou profissionais, familiares ou de amizade. Não há a possibilidade - que só o laboratório proporciona - de experimentar com o corpo diferentes mundos possíveis, efetuando diferentes posições, voltando atrás, refazendo e mudando detalhes a fim de estudar concretamente as micro-consequências de cada alteração. Nesta escala à nossa proporção, que é a da vida, fica também muito mais difícil de ver as dobras acontecendo, pois elas se fazem utilizando a nós próprios como matéria, e, também, num intervalo temporal muito curto. Por isso o dispositivo da escala lupa é tão potente para a investigação dos funcionamentos da relação. Por um lado, ajuda a explicitar a multiplicidade fractal dos acontecimentos, já que ao se reduzir o espaço sem reduzir o mundo - sem fazer maquete, na verdade - os agentes convocados tendem a ser da ordem do que chamamos de coisas ou objetos. Isto funciona muito bem, em especial quando estamos começando a partilhar o AND com um grupo novo, pois praticamente permite ativar um uso tático do nosso próprio preconceito ocidental, que sonega agência aos objetos, ou ao plano não-humano em geral. Com isso, conseguimos entrar num plano mais desarmado de relação, já que não iniciamos por tomar as questões levantadas ali como pessoais; tendemos antes a estar mais sossegados porque assumimos que são 'tão somente coisas'. Logo se nota que essas coisas são corpos tão agentes como nós, têm tendências, vontades, inclinações e que, para jogar com elas sem manipulá -las, é preciso ser atento justamente a essas tendências e inclinações, ou seja, ao que podem (e não podem) enquanto corpos e enquanto agentes que são. Por outro lado, o fato de que ativamos este acontecimento proporcionalmente menor do que nós ao mesmo tempo em que mantemos ativo o acontecimento envolvente, aquele no qual estamos dentro da sala, enquanto grupo, a nos movimentar pelo espaço, a conversar etc., permite ativar uma dimensão de meta-recursividade sincrônica que raramente pode se manifestar na vida quotidiana, e que é muito potente para 'olear a máquina' do pensar-fazer. Mas também há, claro, limitações neste dispositivo laboratorial da lupa.

A _ Será sempre insuficiente ficar apenas na escala da vida ou apenas no laboratório, entenda-se a escala lupa. Porque aí, na escala reduzida, a dimensão de jogo é acentuada, mas não como jogo sério, que envolve todas essas questões da responsabilidade, da atenção às consequências e por aí fora, e que é no fundo, a proposição, mas de um jogo lúdico que corre o risco de cair num 'tudo vale', em que as pessoas por vezes se precipitam por tendência ou impaciência. Porque as pessoas se precipitam seguindo uma ideia de que não há regras quando, na verdade, não há regras preestabelecidas mas há regras emergentes. A escala lupa pode, assim, propiciar uma atitude menos responsável, menos implicada.

F_ Pois é, o dispositivo da lupa é extremamente valioso se for encarado, sobretudo, como uma zona intensiva e intervalar de prática, mas que está sempre a ser 
transposta e devolvida à escala da vida quotidiana. Porque, pelo fato de trabalhar no plano da 'ficção', e também pelo fato de ativar sobretudo agentes não-humanos, o dispositivo da escala lupa suspende um pouco as 'consequências gravíssimas' dos acontecimentos. Embora, dentro da proporção de escala dos agentes que estão ali implicados, as consequências sejam, por vezes, até mesmo 'letais' - uma caneta, um rolo de fita adesiva, todas estas coisas podem 'morrer' ou ficar seriamente danificadas por descuidos ou não-comparências nossas -, como aquele jogo não está sendo jogado numa escala em que nós próprios somos agentes, as consequências não recaem diretamente sobre nós. No jogo mundo-dentro-do-mundo, podemos até usar a matéria dos acontecimentos laboratoriais emergentes para pensar as consequências dos gestos 'irresponsáveis' que possamos ter praticado à escala daquele problema mas, no fim das contas, sempre podemos limpar o espaço e recomeçar. No plano do quotidiano não há esta hipótese de 'zerar'. E será neste plano - o da escala da vida quotidiana, no qual as consequências são mesmo consequências, e são 'do nosso tamanho' - que se jogará efetivamente o AND. Pois no estúdio, mesmo que a gente vá aumentando as dimensões do tabuleiro, a ponto de os agentes à escala daquela zona corresponderem já ao tamanho do nosso corpo e, portanto, a gente poder entrar com o corpo lá - mesmo fazendo isso, estamos trabalhando com uma zona de inconsequência que não se compara à zona de consequência da vida, em que qualquer gesto abre uma série interminável que continua a se propagar indefinidamente.

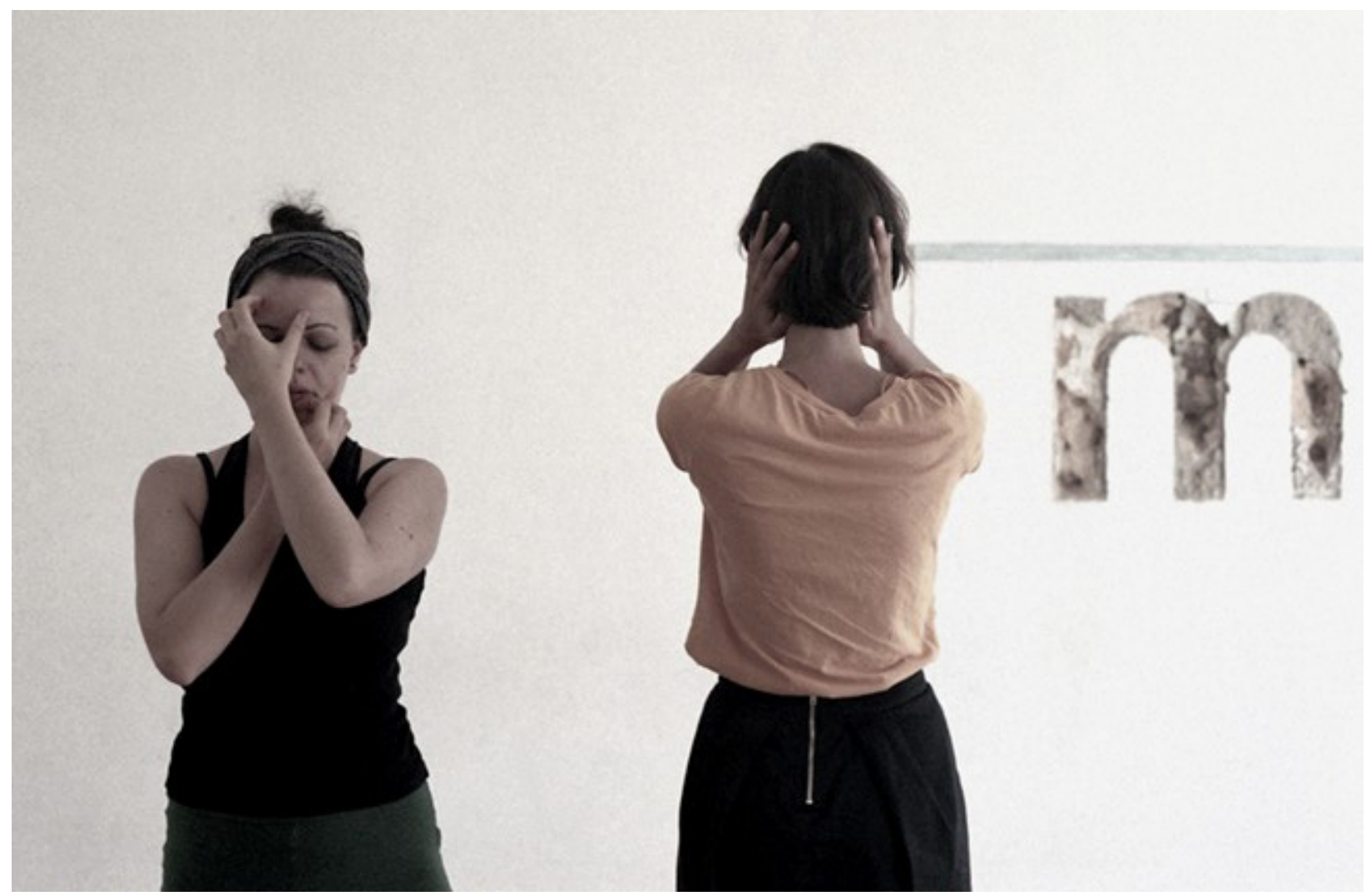

Foto: Filipe dos Santos Barrocas

A _ Eu concordo que, seja qual for a gradação da escala lupa, essa que inclui apenas esses corpos 'menores' dos 'objetos' ou a que já permite a entrada deste corpo-situação que habitamos, a zona de consequência será incomensuravelmente 
mais contida. É frequente pensar na dimensão de clausura do corpo, eu própria usei a expressão habitar, como se o corpo fosse uma carcaça, uma jaula, um recipiente. Mas eu também falei em situação, e passo a enfatizar, porque a situação se pode habitar não de vez mas a cada vez e não tem necessariamente contornos definidos ou, pelo menos, predefinidos. Ou seja, estamos (n)este corpo mais do que somos este corpo, vamos acumulando esses estares em contínuo devir. Há um verso de um poema da Sophia de Mello Breyner Andresen que aproxima este corpo-situação e paisagem: "eu era semelhante às paisagens esperando". Quando se dá esta coabitação de paisagens, a dos muitos mundos que estão em jogo e este novo conjunto de relevos (para usar uma expressão do AND) a que nós chamamos 'corpo', mesmo com todos os seus pontos cegos, há diferenças relativamente à escala menor, a dos 'corpos-objetos', aparentemente mais abarcável.

$\mathrm{F}$ _ O que muda, fundamentalmente, parece-me, é que quando se passa a trabalhar com o corpo como matéria de com-posição, a dimensão perspectivista do trabalho se torna mais explícita. Ela já estava lá, quando os corpos eram os agentes-objetos. Só que, para se pudesse acessar essa dimensão perspectivista na escala do 'menor do que nós', teríamos de ter uma capacidade - que não temos, com o aparato corporal e cognitivo de que dispomos - de nos deslocar e viajar através dos cortes fractais que não nos pertencem - dos microcosmos aos macrocosmos. $\mathrm{E}$ olhar o mundo da perspectiva de uma tampa de caneta, por exemplo. As nanotecnologias, assim como algumas das gigatecnologias de zoom out em larga escala, têm vindo a proporcionar o acesso a perspectivas humanamente inviáveis, funcionando um pouco como prolongamentos corporais. Talvez por isso, o que se propõe com o AND de modo tão analógico e concreto - a fractalidade das coisas ou o "multiverso", ou seja, a co-participação simultânea, porém sempre diferenciada, de uma mesma matéria em diferentes mundos, com diferentes escalas de grandeza, etc. - seja até ligeiramente imaginável hoje. Ainda assim, conseguir ter um vislumbre experiencial do que seja ser tampa de caneta envolverá sempre um esforço muito grande de sintonização. Eu nunca saberei, realmente, o que é estar na posição de uma tampa de caneta. Quando aumentamos as proporções do tabuleiro, não saímos da escala lupa nem da zona segura do estúdio, mas o fato de que entramos na mesma posição em que estavam aqueles agentes-objetos, disponibiliza subitamente a possibilidade que podemos ainda assim não usar - de perceber e experienciar concretamente que nunca está acontecendo só um jogo, que em cada situação estão sempre se (des)dobrando incontáveis camadas de acontecimento em simultâneo. Quando se passa do corpo dos objetos ao nosso corpo como matéria, a rigor, não há mudança de escala - distinguir uma escala corpo de uma escala lupa seria reiterar a cisão entre humanos e não-humanos que a própria escala lupa ajuda a visibilizar como 'pista falsa'. A nossa experiência se altera sobretudo porque o nosso corpo não está apenas colado à nossa perspectiva - no sentido muito imediato de que esta é sempre uma resultante contingente da posição que ocupamos. Culturalmente, ele está incontornavelmente colado ao Eu, ao ego. É um pouco mais do que fixar que o Eu nunca consegue ir a lugar nenhum sem carregar aquilo, o corpo, com ele - porque, tanto nas voltagens mais iluministas quanto nas mais pós-humanistas dos desejos humanos, andou-se 
inconformadamente às voltas com a tentativa de superar o corpo - 'essa coisa limitada e obsoleta!' - para seguir avançando com o Eu. A nossa noção de pessoa mais pervasiva e mais aglutinada ao modo operativo 'é' é aquela que sentencia sobretudo que o corpo é que nunca consegue ir a lugar nenhum sem carregar aquilo, o Eu, com ele. Quando entramos no plano de com-posição com a matéria corpo, há portanto um complicador que se acende instantaneamente: o Eu vai a reboque e tudo o que acontece tende a ser organizado sob a lógica do ponto de vista. Embora se torne prontamente disponível à nossa percepção, a dimensão fractal e perspectivista dos acontecimentos tende a ser obscurecida pela tendência a interpretar, a 'ler' as situações (que entretanto não são textos!), e a tomar tudo como pessoal. Isto tudo se manifesta mesmo no jogo com os agentes-objetos, mas enquanto estamos lidando com os materiais 'menores do que nós' há a possibilidade de gerar um Fora provisório, a partir do qual o funcionamento arraigado do Eu se visibiliza mais facilmente para a própria pessoa. Quando se entra no jogo com o corpo, se agrava a tendência a entrar sempre com o ponto de vista: o Eu não consegue sustentar a espera necessária ao reparar, pois desespera. E é a zona do já-saber que serve de refúgio ao desespero, daí a tendência à paralisia ou à ativação de padrões recorrentes, clichês pessoais, soluções do tipo 'carta na manga', etc. O desafio - sempre o mesmo - se torna mais ostensivo: persistir no reconhecimento da multiplicidade perspectivista dos acontecimentos, não transformar a perspectiva que emerge da posição ocupada pelo corpo num ponto de vista. Conseguir incluir no seu próprio mapa-em-ato - não como ideia ou imagem abstrata, mas como presença efetiva e consequente - a multidão de perspectivas que co-participam num acontecimento. Conseguir sustentar o investimento infinitesimal em escrutinar o que há na sua própria perspectiva - o que ela pode e o que não pode - e, ao mesmo tempo, também o investimento disperso e alargado na clareza de que aquilo não é o mundo inteiro (pois todos os outros, das suas posições, estão também mapeando em simultâneo, e outros mundos não param de se desenhar a partir daquelas mil outras posições). Conseguir adotar como critério de des-cisão isto: isto de ser feito de outros e dos outros também se fazerem a partir de partículas minhas. Alargar a lupa até experimentar usar também o corpo dos ditos sujeitos no mesmo plano que estávamos a usar o corpo dos ditos objetos é um excelente modo de exercitar esse desdobrar. E o plano laboratorial do estúdio permite fazê-lo ativando o funcionamento ficcional tão crucial para realizar (no sentido de dar-se conta) o real (no sentido do que acontece). Mas, para aquém e para além deste plano, está a vida quotidiana, a 'grande outra' da escala lupa, mesmo da lupa mais alargada: aí, não apenas estamos 'completamente dentro', sem foras, sem bordas, sem tréguas, mas estamos numa zona de sombra. Continuamos a ter tudo isto que se visibiliza com os dispositivo da lupa -o perspectivismo, o multiverso, as dobras a acontecer de perto em perto, sem saltos nem cortes - mas o ritmo dos eventos é intenso, o espaço é extenso, as co-implicações são subtis e quase invisíveis. Entretanto, é aqui que toda esta prática de reparagem encontrará a sua justeza de uso e poderá, a cada vez, vir a cumprir a sua pertinência ética.

Recebido em: 01/11/2016

Aprovado em: 08/11/2016 